\title{
Activation of mitochondrial transient receptor potential vanilloid 1 channel contributes to microglial migration.
}

\section{$\operatorname{AUTHOR}(\mathrm{S})$ :}

Miyake, Takahito; Shirakawa, Hisashi; Nakagawa, Takayuki; Kaneko, Shuji

\section{CITATION:}

Miyake, Takahito ...[et al]. Activation of mitochondrial transient receptor potential vanilloid 1 channel contributes to microglial migration.. Glia 2015, 63(10): 1870-1882

\section{ISSUE DATE:}

2015-10

\section{URL:}

http://hdl.handle.net/2433/202049

\section{RIGHT:}

This is the peer reviewed version of the following article: Miyake, T., Shirakawa, H., Nakagawa, T. and Kaneko, S. (2015), Activation of mitochondrial transient receptor potential vanilloid 1 channel contributes to microglial migration. Glia, 63: 1870-18, which has been published in final form at http://dx.doi.org/10.1002/glia.22854. This article may be used for non-commercial purposes in accordance with Wiley Terms and Conditions for Self-Archiving : The full-text file will be made open to the public on 23 MAY 2016 in accordance with publisher's 'Terms and Conditions for Self-Archiving'.; この 論文は出版社版でありません。引用の際には出版社版をご確認ご利用ください。; This is not the published version. Please cite only the published version. 


\section{Activation of mitochondrial transient receptor potential vanilloid 1 channel contributes to microglial migration.}

Takahito Miyake $^{1}$, Hisashi Shirakawa ${ }^{1}$, Takayuki Nakagawa ${ }^{1,2}$, and Shuji Kaneko ${ }^{1}$ ${ }^{1}$ Department of Molecular Pharmacology, Graduate School of Pharmaceutical Sciences, Kyoto University

${ }^{2}$ Department of Clinical Pharmacology and Therapeutics, Kyoto University Hospital,

\section{Correspondence to:}

Hisashi Shirakawa, $\mathrm{PhD}$,

Department of Molecular Pharmacology, Graduate School of Pharmaceutical Sciences, Kyoto University

46-29 Yoshida-shimoadachi-cho, Sakyo-ku, Kyoto, 606-8501, Japan,

Tel/Fax: +81-75-753-4548; E-mail; shirakaw@pharm.kyoto-u.ac.jp

Running title: Mitochondrial TRPV1 in microglial migration

Main points; Activation of TRPV1 triggers an increase in intramitochondrial $\mathrm{Ca}^{2+}$ concentration and following depolarization of mitochondria, which results in mtROS production, MAPK activation, and enhancement of chemotactic activity in microglia.

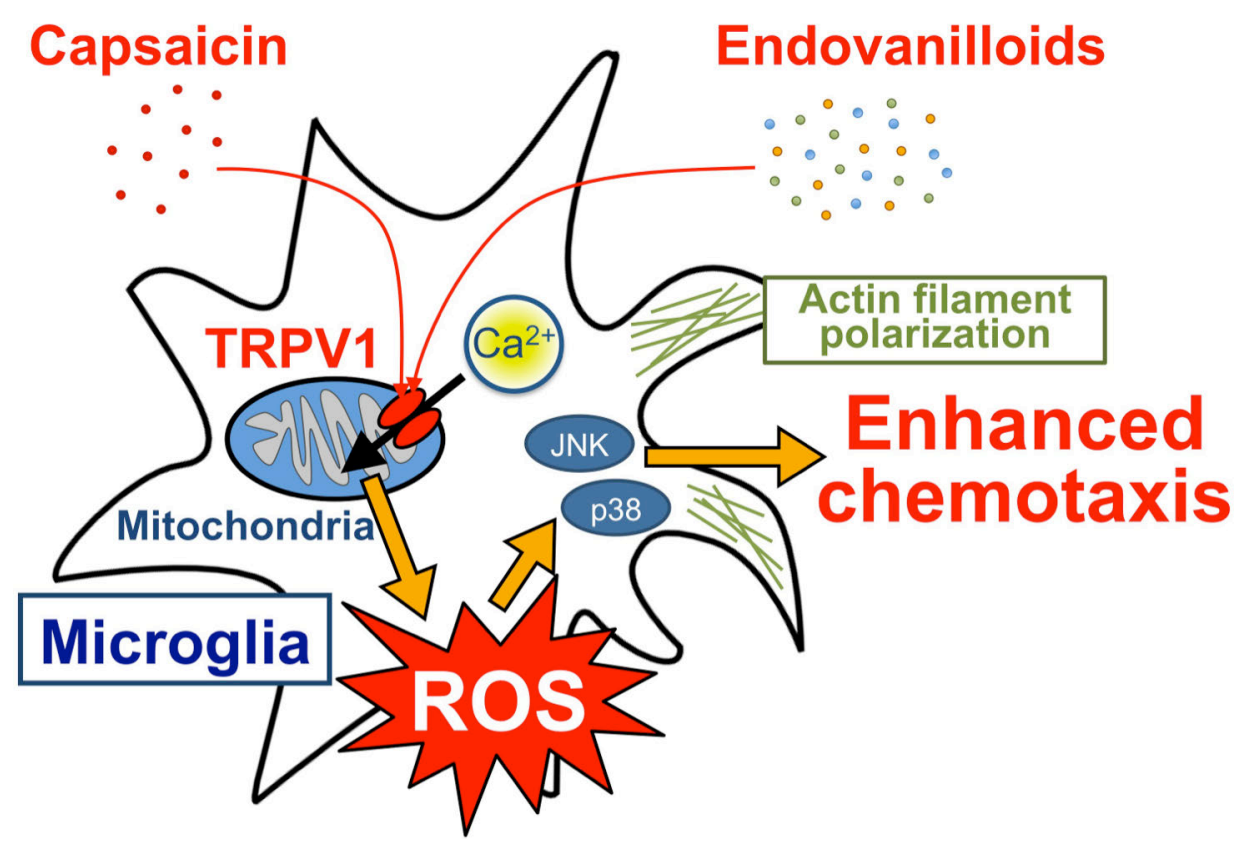




\section{Abstract}

Microglia, the resident immune cells in the brain, survey the environment of the healthy brain. Microglial migration is essential for many physiological and pathophysiological processes. Although microglia express some members of the transient receptor potential (TRP) channel family, there is little knowledge regarding the physiological roles of TRP channels in microglia. Here, we explored the role of TRP vanilloid 1 (TRPV1), a channel opened by capsaicin, heat, protons, and endovanilloids, in microglia. We found that application of capsaicin induced concentration-dependent migration in microglia derived from wild-type mice but not in those derived from TRPV1 knock-out (TRPV1-KO) mice. Capsaicin-induced microglial migration was significantly inhibited by co-application of the TRPV1 blocker SB366791 and the $\mathrm{Ca}^{2+}$ chelator BAPTA-AM. Using RT-PCR and immunocytochemistry, we validated that TRPV1 was expressed in microglia. Electrophysiological recording, intracellular $\mathrm{Ca}^{2+}$ imaging and immunocytochemistry indicated that TRPV1 was localized primarily in intracellular organelles. Treatment with capsaicin induced an increase in intramitochondrial $\mathrm{Ca}^{2+}$ concentrations and mitochondrial depolarization. Furthermore, microglia derived from TRPV1-KO mice showed delayed $\mathrm{Ca}^{2+}$ efflux compared with microglia derived from wild-type mice. Capsaicin-induced microglial migration was inhibited by membrane-permeable antioxidants and MAPK inhibitors, suggesting that mitochondrial TRPV1 activation induced $\mathrm{Ca}^{2+-}$ dependent production of ROS followed by MAPK activation, which correlated with an augmented migration of microglia. Moreover, a mixture of three endovanilloids augmented microglial migration via TRPV1 activation. Together, these results indicate that mitochondrial TRPV1 plays an important role in inducing microglial migration.

Key words: Microglia, Cell movement, TRPV1, Mitochondria, $\mathrm{Ca}^{2+}$ signaling.

\section{Introduction}

Microglia are endogenous resident immunocompetent cells in the CNS (Kettenmann et al., 2011). Microglial migration is essential for many physiological and pathophysiological processes. The amounts of many kinds of chemotactic molecules are regulated by physiological and pathological factors. For example, ATP, which is known to act as a neurotransmitter or a signaling molecule involved in cell death, activates microglial $\mathrm{P}_{2} \mathrm{Y}_{12}$ and $\mathrm{P}_{2} \mathrm{X}_{4}$ receptors and induces chemotaxis through PI3K activation (Honda et al., 2001; Ohsawa et al, 2007). Glutamate, one of the most ubiquitous neurotransmitters in the brain, stimulates microglial chemotactic activity via AMPA receptor and mGluR activation (Liu et al., 2009). The well-known chemokine CX3CL1 (fractalkine) is expressed by neurons in the CNS and modulates microglial behavior to find injured neurons (Cardona et al., 2006; Liang et al., 2009). Microglial behavior is also regulated by cation channels, such as Nav1.6 (Black et al., 2009), Kir2.1 (Muessel et al., 2013) and acid-sensing ion channel (Yu et al., 2015). Although a large number of studies demonstrate how microglial chemotactic activity is regulated, the mechanism is not yet completely 
understood.

Transient receptor potential vanilloid 1 (TRPV1) is one of the most well characterized sensory channels in the TRP channel superfamily (Wu et al., 2010). TRPV1 is expressed in somatosensory neurons and is opened by capsaicin, heat, protons (Caterina et al., 1997; Tominaga et al., 1998), and endovanilloids (Zygmunt et al., 1999). Recent studies reveal that TRPV1 is functionally expressed not only on the plasma membrane but also in intracellular organelles, such as the endoplasmic reticulum (ER) (Gallego-Sandín et al., 2009), sarcoplasmic reticulum (Ito et al., 2013), Golgi apparatus (Turner et al., 2003) and mitochondria (Lang et al., 2014). TRPV1 is expressed not only in neurons but also in astrocytes (Mannari et al., 2013; Ho et al., 2014) and immune cells, such as monocytes (Schilling et al., 2009), macrophages (Fernandes et al., 2012), dendritic cells (Basu et al., 2005), and T cells (Bertin et al., 2014).

Microglia express several types of TRP channels. For instance, activation of the TRPV4 channel attenuates the driving force of extracellular $\mathrm{Ca}^{2+}$ and suppresses microglial activation (Konno et al., 2012). Lipopolysaccharide (LPS) and IFN $\gamma$ activate TRPM2-mediated $\mathrm{Ca}^{2+}$ signaling, which in turn increases downstream p38 MAPK and JNK signaling and results in increased nitric oxide (NO) production (Miyake et al., 2014). Brain-derived neurotropic factor (BDNF) induces sustained intracellular $\mathrm{Ca}^{2+}$ elevation through the upregulation of surface TRPC3 channels, and TRPC3 channels contribute to the BDNF-induced suppression of NO production (Mizoguchi et al., 2014). Some reports also indicate that microglia express functional TRPV1, and its activation causes cell death (Kim et al., 2006), promotes phagocytosis (Hassan et al., 2014), ROS generation (Schilling et al., 2011; Park et al, 2012), and cytokine production (Sappington et al., 2008). However, other contributions of TRPV1 to microglial physiological functions remain unknown. Although TRPV1 blockade inhibits LPC-induced migration in monocytes (Schilling et al., 2009) and TRPV1 activation directly induces migration in dendritic cells (Basu et al., 2005), the molecular details by which TRPV1 activation induces cell migration is still unclear. Here, we demonstrate that TRPV1 contributes to microglial migration using TRPV1 knock-out (TRPV1-KO) mice. The effects of endovanilloids, physiological agonist candidates of TRPV1, were also examined.

\section{Materials and Methods Animals}

All experiments were conducted in accordance with the ethical guidelines of the Kyoto University Animal Research Committee. TRPV1-KO mice were a gift from Dr. David Julius (University of California, San Francisco). The mice were maintained at a constant ambient temperature of $24 \pm 1^{\circ} \mathrm{C}$ under a $12 \mathrm{~h}$ light/dark cycle with free access to food and water.

\section{Mouse primary cultured microglia}

Primary microglial cultures were prepared from newborn wild-type (WT) and TRPV1-KO mice (1-2 days old). Dissociated cells were seeded on $75 \mathrm{~cm}^{2}$ flasks in Dulbecco's modified Eagle's medium (DMEM, D5796, Life Technologies, Carlsbad, 
CA) supplemented with 10\% heat-inactivated FBS, $5 \mu \mathrm{g} / \mathrm{mL}$ insulin (Sigma, St. Louis, MO) and a 1\% penicillin/streptomycin mixed solution (Nacalai Tesque, Kyoto, Japan) and maintained at $37^{\circ} \mathrm{C}$ in a humidified $5 \% \mathrm{CO}_{2}$ atmosphere. After $2-3$ weeks, the primary mixed glial cultures in flasks were shaken for 90 min at 150 $\mathrm{rpm}$. The detached cells were plated on $35^{-\mathrm{mm}}$ dishes $\left(1.0 \times 10^{6} \mathrm{cells} / \mathrm{dish}\right)$, or cover glasses (10 mm diameter, $5 \times 10^{4}$ cells/glass) for each experiment and used within 3 days.

\section{Cell line culture and transfection}

Human embryonic kidney-derived 293T (HEK293T) cells were cultured in DMEM modified with GlutaMAX (10566-016, Life Technologies) containing 10\% heat-inactivated $\mathrm{FBS}$ and maintained at $37^{\circ} \mathrm{C}$ in a humidified $5 \% \mathrm{CO}_{2}$ atmosphere. For electrophysiological experiments, HEK293T cells in $35 \mathrm{~mm}$ dishes were transfected with $2.56 \mu \mathrm{g}$ of pCIneo-rTRPV1 and $0.64 \mu \mathrm{g}$ of pEGFP-C3 using $4 \mu \mathrm{L}$ of Lipofectamine 2000 reagent (Life Technologies) in $1 \mathrm{~mL}$ of Opti-MEM (Life Technologies) for $4-5 \mathrm{~h}$ at $37^{\circ} \mathrm{C}$ in a humidified $5 \% \mathrm{CO}_{2}$ atmosphere. After the transfection, the medium was changed to $2 \mathrm{~mL}$ of culture medium. After 1-2 days, the cells were removed from the dish using a solution containing $0.05 \%$ trypsin and $0.53 \mathrm{mM}$ EDTA (Nacalai Tesque), collected with centrifugation, resuspended in culture medium and attached to coverslips that were pretreated with poly-L-lysine (Sigma). For confocal microscopy, HEK293T cells stably expressing rTRPV1 channel were used as described above (except for the transfection process).

\section{Measurement of NO accumulation}

The NO production was analyzed by measuring the accumulated level of its stable metabolite (nitrite) in the culture media with the Griess reaction. Culture medium $(40 \mu \mathrm{L})$ was added to 96 -well plates and mixed with an equal volume of Griess reagent $\quad(1 \%$ sulfanilamide, $2.5 \%$ phosphoric acid, and $0.1 \%$ naphthylethlenediamine dihydrochloride) for $10 \mathrm{~min}$ at room temperature. The absorbance of the diazonium compound was measured at $540 \mathrm{~nm}$ using a microplate reader (Model 680; Bio-Rad). The absolute levels of nitrite were determined with reference to a standard curve obtained from defined concentrations of sodium nitrite (Sigma).

\section{ELISA}

The levels of TNF- $\alpha$ and IL- 6 in the culture media were determined using mouse TNF- $\alpha$ and IL-6 ELISA kits (R \& D Systems, Minneapolis, MN) in accordance with the manufacturer's protocols. Culture medium suspected of having levels of cytokines/chemokines above the linear range of the standard curve was diluted appropriately in accordance with the manufacturer's protocols. Every sample was assayed in duplicate in the same plate. Absorbance was measured using a microplate reader (Model 680; Bio-Rad, Hercules, CA).

\section{Confocal microscopy}

Cells on coverslips were fixed with 4\% PFA and then permeabilized with PBS containing $3 \%$ BSA and $0.1 \%$ Triton X-100 for 15 min. For TRPV1 detection, cells 
were incubated with rabbit polyclonal anti-TRPV1 (1:200; Alomone Labs, Jerusalem, Israel) for $3 \mathrm{~h}$ at room temperature, followed by incubation with the Alexa Fluor 594-conjugated donkey anti-rabbit secondary antibody (1:200; Life Technologies) for $1.5 \mathrm{~h}$ at room temperature. For detection of subcellular organelles, cells were incubated overnight at $4^{\circ} \mathrm{C}$ with rat monoclonal anti-mouse LAMP1 (1:100; eBioscience, San Diego, CA), goat polyclonal anti-58K Golgi protein (1:50; Abcam, Cambridge, MA), and goat polyclonal anti-calregulin (1:50; Santa Cruz, Dallas, TX) along with anti-TRPV1 antibody, and then incubated with Alexa Fluor 488-conjugated goat anti-rat or donkey anti-goat secondary antibodies (1:20,000 or 1:200, respectively; Life Technologies) or with Alexa Fluor 594-conjugated donkey anti-rabbit secondary antibody (1:200; Life Technologies) for $1.5 \mathrm{~h}$ at room temperature. For detection of mitochondria, living cells on coverslips were incubated in Krebs-Ringer buffer (which contained the following, in mM: $140 \mathrm{NaCl}$, $5 \mathrm{KCl}, 1 \mathrm{MgCl}_{2}, 2 \mathrm{CaCl}_{2}, 10 \mathrm{HEPES}$, and $10 \mathrm{D}$-glucose, adjusted to $\mathrm{pH} 7.4$ with $\mathrm{NaOH})$ with MitoTracker Red (Molecular Probes, Eugene, OR) $(1 \mu \mathrm{M})$ for $40 \mathrm{~min}$ at $37^{\circ} \mathrm{C}$ in a humidified $5 \% \quad \mathrm{CO}_{2}$ atmosphere. Cells were rinsed twice with Krebs-Ringer buffer, fixed, permeabilized, and then incubated with rabbit polyclonal anti-TRPV1 (1:200) for $3 \mathrm{~h}$ at room temperature, followed by incubation with the Alexa Fluor 488-conjugated donkey anti-rabbit secondary antibody (1:200; Life Technologies) for $1.5 \mathrm{~h}$ at room temperature. To detect membrane ruffling, fixed cells were incubated with the Alexa Fluor 488-conjugated phalloidin (1:200; Life Technologies) for $1 \mathrm{~h}$ at room temperature as previously described (Shirakawa et al., 2010). After mounting the coverslips in the anti-fading medium Vectashield or Vectashield with DAPI (Vector Laboratories, Burlingame, CA), the fluorescence immunoimages were acquired with a FluoView FV10i confocal laser-scanning microscope (Olympus, Tokyo Japan).

\section{Electrophysiology}

Whole-cell currents were recorded at room temperature with a pipette made from a 1.5-mm outer-diameter glass capillary with a filament (Narishige, Tokyo, Japan) and pulled using a P-87 micropipette puller (Sutter, Novato, CA). The access resistance ranged from 2 to $5 \mathrm{M} \Omega$ when the pipette was filled with the intracellular solution described below. The extracellular and intracellular solution contained (in $\mathrm{mM}) 140 \mathrm{NaCl}, 5 \mathrm{KCl}, 2 \mathrm{MgCl}_{2}, 2$ EGTA, $10 \mathrm{HEPES}$, and $10 \mathrm{D}$-glucose (adjusted to $\mathrm{pH} 7.4$ with $\mathrm{NaOH}$ ). Current-voltage relationships were measured using voltage ramps $(-100$ to $+100 \mathrm{mV}$ over $200 \mathrm{~ms}, 0.5 \mathrm{~Hz})$. The holding potential was set at 0 $\mathrm{mV}$. Access resistances were compensated by $70 \%$. Patch-clamp recordings were performed using an EPC-10 patch-clamp amplifier (HEKA Instruments, Lambrecht, Germany) and PATCHMASTER software (HEKA). All perfusions were performed with a VC-6 perfusion system (Warner Instruments, Hamden, CT). For analysis, data were filtered at $2.9 \mathrm{kHz}$.

\section{Measurement of intracellular $\mathrm{Ca}^{2+}$ concentration}

Time-lapse imaging of intracellular $\mathrm{Ca}^{2+}$ concentration was examined with the $\mathrm{Ca}^{2+-}$-sensitive fluorescent dye Fura-2 acetoxymethyl ester (Fura-2 AM; Dojindo Laboratory, Kumamoto, Japan) using a fluorescence imaging system 
(AQUACOSMOS image acquisition software with an ORCA-R2 CCD camera, Hamamatsu Photonics, Shizuoka, Japan). Cells were incubated in Krebs-Ringer buffer containing $5 \mu \mathrm{M}$ Fura-2 AM and 0.005\% Cremophore EL (Sigma) for 40 min at $37^{\circ} \mathrm{C}$ in a humidified $5 \% \mathrm{CO}_{2}$ atmosphere. After rinsing with the buffer, the cells were transferred to a recording chamber on the stage of an IX71 inverted fluorescence microscope (Olympus). The Fura-2 fluorescence obtained by excitation wavelengths of $340 \mathrm{~nm}$ and $380 \mathrm{~nm}$ and emission wavelengths of $500 \mathrm{~nm}$ was recorded at $2 \mathrm{~s}$ intervals at room temperature. Capsaicin perfusion was performed with a VC-6 perfusion system (Warner Instruments). Additional drug solutions were perfused into the recording chamber. The rate of $\mathrm{Ca}^{2+}$ influx or efflux was obtained by measuring the initial slope of $\mathrm{Ca}^{2+}$ rise or decline, respectively. The maximal value of the normalized fluorescence intensity was taken as the peak amplitude or influx. The width of the peak at its half-amplitude $\left(t_{1 / 2}\right)$ was determined to evaluate the response time.

\section{Measurement of intramitochondrial $\mathrm{Ca}^{2+}$ concentration}

Time-lapse imaging of intramitochondrial $\mathrm{Ca}^{2+}$ concentration was estimated with the cationic $\mathrm{Ca}^{2+-}$ sensitive fluorescent dye Rhod-5N acetoxymethyl ester (Rhod-5N AM; AAT Bioquest, Sunnyvale, CA) using an A1R $\mathrm{MP}^{+}$multiphoton confocal microscope (Nikon) and NIS-Elements $\mathrm{C}$ acquisition and analysis software (Nikon). Cells on a $35-\mathrm{mm}$ glass-bottom dish were incubated in recording buffer (which contained, in $\mathrm{mM}, 120 \mathrm{NaCl}, 6 \mathrm{KCl}, 2 \mathrm{MgCl}_{2}, 0.3 \mathrm{CaCl}_{2}, 10 \mathrm{HEPES}, 12 \mathrm{D}$-glucose, and 12 sucrose, adjusted to $\mathrm{pH} 7.4$ with $\mathrm{NaOH}$ ) with $5 \mu \mathrm{M}$ Rhod-5N AM and $0.005 \%$ Cremophore EL (Sigma) for $50 \mathrm{~min}$ at $37^{\circ} \mathrm{C}$ in a humidified $5 \% \mathrm{CO}_{2}$ atmosphere. After rinsing with the buffer, Rhod $-5 \mathrm{~N}$ fluorescence obtained by excitation wavelengths of $551 \mathrm{~nm}$ and emission wavelengths of $576 \mathrm{~nm}$ was recorded at $6 \mathrm{~s}$ intervals at room temperature. Drug solutions were applied by perfusion to the recording chamber.

\section{Mitochondrial membrane potential assay}

The mitochondrial membrane potential $(\mathrm{m} \Delta \Psi)$ was determined with a JC-1 mitochondrial membrane potential assay kit (Cayman, Ann Arbor, MI). Cells on a glass-bottom dish were treated with drugs for $24 \mathrm{~h}$. The $\mathrm{JC}-1$ dye in culture medium was added to the cell culture and incubated for $30 \mathrm{~min}$ at $37^{\circ} \mathrm{C}$ in a humidified $5 \%$ $\mathrm{CO}_{2}$ atmosphere. Microscopy was performed using a FluoView FV10i confocal laser-scanning microscope (Olympus). Images were captured in five randomly selected microscopic fields for each treatment by an investigator who was blind to the experimental conditions. The ratio of the fluorescent intensity obtained by the excitation/emission of $578 / 599 \mathrm{~nm}\left(\mathrm{~F}_{578}\right)$ to the fluorescent intensity obtained by the excitation/emission of $485 / 535 \mathrm{~nm}\left(\mathrm{~F}_{485}\right)$, namely $\mathrm{F}_{578} / \mathrm{F}_{485}$, was calculated to quantitate $\mathrm{m} \Delta \Psi$.

\section{Scratch-wound assay}

Microglia were plated in a $35-\mathrm{mm}$ dish. After 1 day, cell cultures were scratched with a $1000 \mu \mathrm{L}$ sterile pipette tip. After one wash with culture medium, cells were maintained at $37^{\circ} \mathrm{C}$ in a humidified $5 \% \mathrm{CO}_{2}$ atmosphere. Phase contrast images of 
the wounds were acquired at $0 \mathrm{~h}$ and $24 \mathrm{~h}$ after scratching using a TE300 inverted fluorescence microscope (Nikon) and a DS-5Mc-L2 digital camera system (Nikon).

\section{Chemotactic assay}

The chemotactic assay was performed with transwell-based Chemotaxicell chambers having a $5-\mu \mathrm{m}$ pore size (Kurabo, Osaka, Japan). Microglia were planted in the upper chamber or chamber-free blank well at a density of $5.0 \times 10^{5}$ cells per well. All drugs were added to the lower chamber or chamber-free well. Cells were allowed to migrate for $24 \mathrm{~h}$ at $37^{\circ} \mathrm{C}$ in a humidified $5 \% \mathrm{CO}_{2}$ atmosphere. The cells that migrated to the bottom of the lower chamber or chamber-free well were examined and captured in two representative microscopic fields by an investigator who was blind to the experimental conditions (each treatment was performed in duplicate chamber-placed wells and one chamber-free well), and the cell numbers in each individual field were counted. The chemotactic ratio was calculated by dividing the cell number of the lower chamber by the cell number of the chamber-free well.

\section{Statistical analyses}

All data are expressed as means \pm SEM. Statistical analyses were performed using Student's $t$-tests, one-way ANOVA followed by Tukey's multiple comparisons tests, and two-way ANOVA followed by Bonferroni post-hoc tests using GraphPad Prism 5 (GraphPad Software, Inc., La Jolla, CA). Probability values less than 5\% $(p<0.05)$ were considered significant.

\section{Results}

\section{Capsaicin induces microglial chemotactic activity}

To explore the physiological role of TRPV1 in microglia, we assessed whether capsaicin affected microglial chemotactic activity using a Boyden chamber assay (Walter et al., 2003). Capsaicin (1-10 $\mu \mathrm{M})$ augmented the chemotactic activity of microglia derived from WT mice in a concentration-dependent manner (Fig. 1A), and this augmentation was significantly inhibited by co-treatment with SB366791 (3 $\mu \mathrm{M})$, a TRPV1 selective blocker (Fig. 1A). By contrast, microglia derived from TRPV1-KO mice showed no change in chemotactic activity after application of capsaicin (Fig. 1B). To investigate the contribution of $\mathrm{Ca}^{2+}$, we simultaneously applied capsaicin with BAPTA-AM $(10 \mu \mathrm{M})$, an intracellular $\mathrm{Ca}^{2+}$ chelator. The BAPTA-AM significantly suppressed the capsaicin-induced chemotaxis in microglia derived from WT mice (Fig. 1A), but not in microglia derived from TRPV1-KO mice (Fig. 1B). All the treatments did not affect cell viability (Supplementary figure 1 and 2), and SB366791 and BAPTA-AM alone did not affect the basal microglial cell migration (Supplementary figure 3).

To confirm the effect of capsaicin on microglial chemotactic activity, we performed a scratch-wound assay (Siddiqui et al., 2012). Treatment with capsaicin $(10 \mu \mathrm{M})$ for $24 \mathrm{~h}$ increased the number of the microglia populating a cell-free area (Fig. 1C). Next, we investigated the effect of capsaicin on microglial membrane ruffling (Honda et al., 2001). Phalloidin staining demonstrated that $10 \mu \mathrm{M}$ capsaicin stimulation for $24 \mathrm{~h}$ caused membrane ruffling in microglia derived from WT mice 
(Fig. 1D, white arrow). Co-treatment of microglia with SB366791 (3 $\mu \mathrm{M})$, a selective TRPV1 blocker, inhibited the capsaicin-induced membrane ruffling (Fig. 1D). By contrast, microglia derived from TRPV1-KO mice showed no capsaicin-induced membrane ruffling (Fig. 1E).

\section{Activation of TRPV1 is not involved in other cellular functions}

To exclude any unanticipated effects of TRPV1 deletion on microglial chemotactic activity, we investigated ATP-induced chemotaxis in microglia. Treatment with ATP $(100 \mu \mathrm{M})$ for $24 \mathrm{~h}$ induced robust chemotactic activity in microglia derived from both WT (Fig. 2A) and TRPV1-KO mice (Fig. 2B), indicating that ATP-induced chemotaxis is independent of TRPV1 activation. Furthermore, TRPV1 activation with capsaicin followed by combined treatment with LPS (100 ng/mL) and IFN $\gamma(10$ $\mathrm{ng} / \mathrm{mL}$ ) for $48 \mathrm{~h}$ had no effect on the production of NO (Figs. $2 \mathrm{C}$ and $2 \mathrm{D}$, and Supplementary figure 4), TNF- $\alpha$ (Figs. 2E and 2F), and IL-6 (Figs. 2G and 2H) in microglia, although capsaicin administration enhanced $\mathrm{TNF}-\alpha$ release in a TRPV1-independent manner by unknown mechanisms (Figs. 2E and 2F). These data indicate that activation of TRPV1 has little effect on other cellular functions such as ATP-induced chemotaxis and the release of inflammatory molecules in microglia.

\section{TRPV1 is expressed in intracellular organelles in cultured mouse microglia}

To determine whether murine-cultured microglia expressed TRPV1, we examined the expression of TRPV1 using immunohistochemistry and revealed that TRPV1 channels in HEK293T cells that were stably expressing these channels were located on the plasma membrane (Fig. 3A), whereas microglia derived from WT mice exhibited a punctate cytoplasmic distribution of TRPV1 channels (Fig. 3A). By contrast, no immunoreactivity was observed in microglia derived from TRPV1-KO mice (Fig. 3A). Presumably, $\sim 60 \%$ of microglia expressed detectable TRPV1 immunoreactivity (Fig. 3B). These results indicate that TRPV1 is expressed in a large population of microglia and likely located in intracellular organelles rather than on the plasma membrane.

To determine the intracellular localization of TRPV1 in microglia, we performed co-immunostaining of TRPV1 and intracellular organelles. Analysis using confocal microscopy revealed that TRPV1 showed co-localization with the ER marker calregulin, the Golgi marker 58K Golgi protein, the lysosomal marker lysosomal-associated membrane protein 1 (Lamp1) and the mitochondrial marker MitoTracker Red (Fig. 3C). These results indicate that TRPV1 is expressed in intracellular organelles in microglia.

\section{TRPV1 regulates mitochondrial $\mathrm{Ca}^{2+}$ uptake in microglia}

To confirm that the TRPV1 channel was not present in the plasma membrane in microglia, we assessed TRPV1 expression directly using whole-cell patch-clamp recordings. Whereas HEK293T cells transiently expressing rat TRPV1 showed strong, concentration-dependent capsaicin-evoked currents (Fig. 4A), microglia showed no capsaicin-evoked current (Fig. 4B). Capsaicin (10 $\mu \mathrm{M})$ subtly inhibited 
the inward current in microglia, although this inhibition was not blocked by co-application of SB366791 $(3 \mu \mathrm{M})$ (data not shown). This observed capsaicin-induced inhibition of inward currents might be attributed to the inhibitory effect of capsaicin on potassium currents (Kuenzi et al., 1996). To address the possibility that TRPV1 channel is located in intracellular organelles and activation of TRPV1 contributes to increases in intracellular $\mathrm{Ca}^{2+}$ concentration, we examined the effect of capsaicin on microglial intracellular $\mathrm{Ca}^{2+}$ concentration using the high affinity $\mathrm{Ca}^{2+}$ indicator Fura-2 AM. No response to capsaicin was observed in microglia (Fig. 4C). Taken together, these results suggest that TRPV1 is not located on the plasma membrane and that TRPV1 stimulation does not contribute to the $\mathrm{Ca}^{2+}$ influx across the plasma membrane or to the $\mathrm{Ca}^{2+}$ release from intracellular stores.

Mitochondria are involved in $\mathrm{Ca}^{2+}$ buffering, and this mitochondrial $\mathrm{Ca}^{2+}$ signaling has a role in controlling cell metabolism, cell-type specific functions and cell survival (Rizzuto et al., 2012). To investigate the effect of TRPV1 activation on mitochondria, we performed intramitochondrial $\mathrm{Ca}^{2+}$ imaging using the low affinity cationic $\mathrm{Ca}^{2+}$ indicator Rhod-5N AM. Capsaicin $(10 \mu \mathrm{M})$ evoked an increase of the intramitochondrial $\mathrm{Ca}^{2+}$ concentration in microglia derived from WT mice, but this effect was significantly suppressed in microglia derived from TRPV1-KO mice (Figs. $4 \mathrm{D}$ and $4 \mathrm{E}$ ). To explore the involvement of TRPV1 in mitochondrial $\mathrm{Ca}^{2+}$ buffering, we observed the ATP-induced store-operated $\mathrm{Ca}^{2+}$ entry (SOCE) in microglia derived from both WT and TRPV1-KO mice. Although the amplitude of the SOCE was similar in both genotypes (Figs. $4 \mathrm{~F}$ and $4 \mathrm{G}$ ), the time to half-amplitude $\left(\mathrm{t}_{1 / 2}\right)$ was significantly prolonged in microglia derived from TRPV1-KO mice compared with that in microglia derived from WT mice (Figs. $4 \mathrm{~F}$ and $4 \mathrm{H}$ ). Furthermore, blockade of TRPV1 with SB366791 $(3 \mu \mathrm{M})$ significantly prolonged the $\mathrm{t}_{1 / 2}$, but did not change the amplitude of ATP-induced SOCE, similar to microglia derived from TRPV1-KO mice (Figs. 4F-H). The influence of TRPV1 activation on the $\mathrm{m} \Delta \Psi$ was also investigated using JC-1 dye. Treatment with capsaicin $(10 \mu \mathrm{M})$ for $24 \mathrm{~h}$ showed a significant decrease in the $\mathrm{m} \Delta \Psi$ in microglia derived from WT mice, and this decrease was blocked by the co-administration of SB366791 (3 $\mu \mathrm{M})$ (Fig. 4I). No change in the $\mathrm{m} \Delta \Psi$ was observed in microglia derived from TRPV1-KO mice (Fig. $4 \mathrm{~J})$. These results suggest that activation of TRPV1 evokes a $\mathrm{Ca}^{2+}$ influx into mitochondria, followed by mitochondrial depolarization in microglia.

\section{TRPV1 activation enhances microglial chemotactic activity via mitochondrial ROS production followed by p38 MAPK and JNK activation}

To determine the role of mitochondria in capsaicin-induced chemotaxis (as shown in Fig. 1), we investigated the effect of rotenone, a specific inhibitor of mitochondrial electron transport complex I, using the Boyden chamber assay. Although rotenone $(0.3 \mu \mathrm{M})$ co-treatment had no effect on the ATP-induced chemotaxis, rotenone significantly inhibited the capsaicin-induced chemotaxis (Fig. 5A). Mitochondrial $\mathrm{Ca}^{2+}$ uptake induces mitochondrial depolarization, resulting in generation of ROS (Brookes et al., 2004; Ferraiuolo et al., 2011; Takeuchi et al., 2014). Because capsaicin treatment induced TRPV1-dependent mitochondrial 
depolarization in microglia (Figs. 4I and 4J), we assessed the effects of various antioxidants on capsaicin-induced chemotaxis to examine the involvement of mitochondrial ROS (mtROS). The membrane-permeable antioxidants EUK-134 (3 $\mu \mathrm{M}), \mathrm{Mn}$-TBAP $(30 \mu \mathrm{M})$ and TEMPOL $(1 \mathrm{mM})$ significantly inhibited microglial chemotaxis, whereas the membrane-impermeable antioxidants glutathione (1 mM) and vitamin $\mathrm{C}(100 \mu \mathrm{M})$ showed no significant effects (Fig. 5B), suggesting that intracellular ROS have an important role in capsaicin-induced chemotaxis. These results indicate that capsaicin induces microglial chemotaxis through mtROS generation.

To confirm whether ROS induced microglial chemotaxis, we investigated the effect of hydrogen peroxide $\left(\mathrm{H}_{2} \mathrm{O}_{2}\right)$ on microglial chemotactic activity. Hydrogen peroxide $(10 \mu \mathrm{M})$ significantly induced chemotaxis in microglia derived from WT mice (Fig. $5 \mathrm{C})$, but this chemotaxis was not blocked by the TRPV1 blocker SB366791 $(3 \mu \mathrm{M})$ (Fig. 5C) and was also observed in microglia derived from TRPV1-KO mice (Fig. $5 \mathrm{D})$, suggesting that this $\mathrm{H}_{2} \mathrm{O}_{2}$-induced chemotaxis is TRPV1-independent. Furthermore, the $\mathrm{H}_{2} \mathrm{O}_{2}$-induced chemotaxis was significantly inhibited by EUK-134 $(3 \mu \mathrm{M})$ in microglia derived from both WT (Fig. 5C) and TRPV1-KO mice (Fig. 5D).

To unravel the downstream signaling of this phenomenon, we examined the effect of a MAPK inhibitor on the $\mathrm{H}_{2} \mathrm{O}_{2}$-induced chemotaxis. Whereas the ERK inhibitor PD98059 $(10 \mu \mathrm{M})$ had no effect on the $\mathrm{H}_{2} \mathrm{O}_{2}$-induced chemotaxis, the p38 MAPK inhibitor SB203580 $(30 \mu \mathrm{M})$ and the JNK inhibitor SP600125 $(30 \mu \mathrm{M})$ significantly inhibited the $\mathrm{H}_{2} \mathrm{O}_{2}$-induced chemotaxis (Fig. 5C). Similarly, the capsaicin-induced chemotaxis was also significantly inhibited by SB203580 $(30 \mu \mathrm{M})$ and SP600125 (30 $\mu \mathrm{M})$, but not by PD98059 $(10 \mu \mathrm{M})$ (Fig. 5E). All the inhibitors did not affect the cell viability (Supplementary figure 1 and 2) and basal microglial cell migration (Supplementary figure 3). These results suggest that the mtROS induced by capsaicin treatment triggers microglial chemotaxis via activation of p38 MAPK and JNK.

\section{Endovanilloids induce microglial chemotaxis via a TRPV1-dependent mechanism}

Our search for an endogenous TRPV1 agonist focused on endovanilloids because they are released in physiological (Maccarrone et al., 2008; Tanimura et al., 2010) and pathological (Franklin et al., 2003; Stock et al., 2012) conditions in the brain. We investigated the effect of three endovanilloids, arachidonylethanolamide (AEA), oleoylethanolamide (OEA), and palmitoylethanolamide (PEA), on microglial chemotactic activity and found that the combination of these three endovanilloids was necessary to induce microglial chemotaxis (relative chemotactic ratio vs. control, $1.378 \pm 0.125, p>0.05$ in AEA $(30 \mu \mathrm{M}) ; 0.848 \pm 0.079, p>0.05$ in AEA (30 $\mu \mathrm{M})+$ OEA $(1 \mu \mathrm{M}) ; 0.961 \pm 0.037, p>0.05$ in AEA $(30 \mu \mathrm{M})+$ PEA $(1 \mu \mathrm{M})$; and 1.967 $\pm 0.482, p<0.05$ in AEA $(30 \mu \mathrm{M})+$ OEA $(1 \mu \mathrm{M})+$ PEA $(1 \mu \mathrm{M}), n=4)$. Furthermore, the chemotaxis induced by the mixture of the three endovanilloids was inhibited by EUK-134 (3 $\mu \mathrm{M})$ (Fig. 6A) but was not observed in microglia derived from TRPV1-KO mice (Fig. 6B). To determine whether the mixture of these three endovanilloids induced mitochondrial depolarization, we evaluated the $\mathrm{m} \Delta \Psi$ in microglia using JC-1 dye. The mixture of the three endovanilloids induced 
mitochondrial depolarization in microglia derived from WT mice, and this depolarization was blocked by SB366791 (3 $\mu \mathrm{M})$ (Fig. 6C). There was no effect in microglia derived from TRPV1-KO mice (Fig. 6D). These data suggest that the mixture of these three endovanilloids induces microglial chemotaxis via TRPV1 activation, mitochondrial depolarization, and mtROS production.

\section{Discussion}

In this study, we demonstrated that TRPV1 is functionally expressed in mitochondria and its activation triggers an increase in intramitochondrial $\mathrm{Ca}^{2+}$ concentration, depolarization of mitochondria, resultant mtROS production and enhancement of chemotactic activity in microglia.

Endovanilloids are one group of endogenous TRPV1 agonists (Zygmunt et al., 1999), and activation of postsynaptic TRPV1 by AEA plays a pivotal role in the induction of long-term depression in hippocampal dentate gyrus granular cells (Chávez et al., 2010) and in dopamine D2 receptor-expressing medium spiny neurons of the nucleus accumbens (Grueter et al., 2010) under physiological conditions. Moreover, endovanilloids are not only released into the synaptic cleft but also spill over from synapses and bind cannabinoid receptors in astrocytes that modulate neighboring synapses by releasing glutamate (Navarrete et al., 2010). The role of endovanilloids under pathological conditions is also important. Recently, neuronal precursor cells were reported to migrate to high-grade astrocytomas, reduce glioma expansion and prolong survival time by releasing certain endovanilloids that open glioma TRPV1 channels in the ER and induce glioma cell death (Stock et al., 2012). In that study, they examined three endovanilloids (AEA, OEA, and PEA) and found that not one or two but all three endovanilloids were necessary to cause TRPV1-mediated glioma cell death, consistent with our result that the combination of three endovanilloids was needed to induce microglial migration. Glioma tissue consists of tumor cells and up to $30 \%$ microglia or macrophages, and the microglia are attracted to the glioma site and accumulate at its margins, in particular (Hanisch et al., 2007). In several pathological conditions, the concentrations of endovanilloids in the CNS are increased in several area of the brain. For instance, Panikashvili et al. (2001) demonstrate that the level of 2-arachidonoyl glycerol, which behaves also as an endogenous agonist of TRPV1 (Zygmunt et al., 2013), is significantly elevated after closed head injury (CHI) in mice. Marsicano et al. (2003) show that the amount of hippocampal AEA is significantly increased after kainic acid injection-induced excessive seizures. Furthermore, PEA and AEA are greatly increased in mouse cerebral cortex after focal ischemia and PEA potentiates AEA-induced microglial migration, without affecting other parameters of microglial activation, such as proliferation, particle engulfment, and NO production (Franklin et al., 2003). What is particularly interesting in that report with regard to the present study is that the receptors engaged by PEA are pharmacologically distinct from CB1 and CB2 cannabinoid receptors. This implies that TRPV1 may contribute to this phenomenon because in our study capsaicin did not affect the NO production induced by LPS/IFN $\gamma$ but induced migration. Thus, TRPV1-mediated microglial chemotaxis may have an 
important role in microglial accumulation via a mechanism involving endovanilloids.

TRPV1 can also be activated or modified by intracellular signaling following the activation of other receptors. For example, $\mathrm{PKC} \varepsilon$ is bound to the inner mitochondrial membrane and phosphorylates the mitochondrial $\mathrm{K}_{\mathrm{ATP}}$ channel to modulate its activity (Costa et al., 2008), indicating that $\mathrm{PKC} \varepsilon$ is functionally located on the inner mitochondrial membrane. In addition, hypoxia, one of the main complications in diabetes, induces translocation of $\mathrm{PKC} \varepsilon$ to the plasma membrane, and PKCe phosphorylates the serine residues of TRPV1 (Numazaki et al., 2002), which results in the potentiation of TRPV1 and the genesis of early diabetic neuropathy (Ristoiu et al., 2011). Moreover, activation of PLC downstream of bradykinin or TrkA receptors by their agonists may potentiate TRPV1 through direct activation of lipid metabolites, such as arachidonic acid and the hydroperoxyeicosatetraenoic acid generated by phospholipase A2 and lipoxygenase (Hwang et al., 2000). Although the present study suggests that direct activation of TRPV1 augmented chemotactic activity in microglia, we cannot exclude the possibility that microglia sense other signals through their receptors and migrate to the injury site via PKCe and PLC activation followed by TRPV1 activation because microglia express functional metabotropic receptors, such as mGluRs (Byrnes et al., 2009) and P2Y receptors (Koizumi et al., 2013).

In the present study, capsaicin induced an increase in the intracellular mitochondrial $\mathrm{Ca}^{2+}$ concentration and mitochondrial depolarization, whereas capsaicin induced no responses in the electrophysiological and intracellular $\mathrm{Ca}^{2+}$ imaging experiments in microglia. Mitochondria are capable of taking up $\mathrm{Ca}^{2+}$ ions from the cytosol (Deluca et al., 1961; Vasington et al., 1962). Although the intramitochondrial $\mathrm{Ca}^{2+}$ concentration is higher than the intracellular $\mathrm{Ca}^{2+}$ concentration, the $\mathrm{m} \Delta \Psi$ is sufficient to induce $\mathrm{Ca}^{2+}$ uptake rather than $\mathrm{Ca}^{2+}$ release (Rizzuto et al., 2012). In our study, microglia derived from TRPV1-KO mice showed a prolonged $t_{1 / 2}$ of the $\mathrm{Ca}^{2+}$ response induced by $10 \mu \mathrm{M}$ ATP compared with microglia derived from WT mice. Thus, TRPV1 appears to be located neither on the plasma membrane nor on the intracellular membranes of the compartment of the $\mathrm{Ca}^{2+}$ store, but is likely located in mitochondria.

It is known that mtROS plays a pivotal role in regulating cellular functions. For instance, in cultured human umbilical vein endothelial cells, VEGF promotes mtROS production and induces cell migration through Rac1 activation (Wang et al., 2011). In murine peritoneal macrophages, lysophosphatidylcholine, released from apoptotic cells, enhances mtROS production and triggers chemotactic activity through AMPK activation (Jiang et al., 2013). These results imply that mitochondria in microglia may also regulate chemotactic activity, in addition to regulating production of pro-inflammatory mediators, which is triggered by the activation of nuclear factor kappa-light-chain-enhancer of activated B cells and MAPK signaling following mtROS production induced by increased mitochondrial fission in LPS-stimulated microglia (Park et al., 2013). Furthermore, different mtROS levels regulate different cellular functions. Whereas high levels of mtROS induce apoptosis and autophagy, low levels of mtROS participate in the process of hypoxia adaptation, and moderate levels of mtROS are involved in regulating the 
production of pro-inflammatory cytokines by directly activating the inflammasome and MAPK (Li et al., 2013). Because $10 \mu \mathrm{M}$ capsaicin did not induce cell death in microglia in the present study (Supplementary figure 1), and the expression level of TRPV1 is not changed between peritoneal cells obtained from sham and cecal ligation and puncture model mice (Fernandes et al., 2012), our data indicated that mitochondrial depolarization induced by TRPV1 activation produced low or moderate levels of mtROS, which regulated MAPK activity followed by augmentation of microglial chemotaxis and mitochondrial TRPV1 activation may be independent of other microglial functions.

Although previous research has shown that ROS play an important role in cell migration, little is known about the mechanisms underlying ROS-induced augmentation of microglial migration. Recent studies show that $\mathrm{H}_{2} \mathrm{O}_{2}$ has a pivotal role of immediate wound attractant signaling in macrophages of Drosophila embryo (Moreira et al., 2010) and leukocytes of zebrafish in vivo (Niethammer et al., 2009). It has been demonstrated that $\mathrm{H}_{2} \mathrm{O}_{2}$ itself induces chemotactic activity in mouse neutrophils (Klyubin et al., 1996) and in a keratinocyte cell line in vitro (Loo et al., 2011), indicating that extracellular ROS can play an important role in chemoattractant signaling. What then is the role of intracellular ROS in cell migration? ROS can influence F-actin dynamics both directly and indirectly. Migrating cells produce ROS at the membrane ruffles, which directly increases actin polymerization (Ikeda et al., 2005). The indirect regulation of actin dynamics by ROS occurs via activation of redox-sensitive enzymes. For instance, ROS oxidizes tyrosine phosphatase, which induces the decrease in RhoA activity required for Rac-induced formation of membrane ruffles (Nimnual et al., 2003). ROS directly activates $\mathrm{G}_{\text {ai }}$ and $\mathrm{G}_{a o}$ and stimulates the PI3K, Akt, and ERK cascades, which are related to actin organization (Nishida et al., 2000). ROS modulate MAPK signaling (Liu et al., 2009; Bhatt et al., 2002; Ogura et al., 1998; Aikawa et al., 1997; Guyton et al., 1996), and MAPK phosphatase-1 is a central redox-sensitive regulator of monocyte adhesion and chemotaxis (Kim et al., 2012). Thus, the generation of ROS is an important signaling mechanism regulating cell migration.

In conclusion, this study indicates that microglial TRPV1 is located in mitochondria, and the activation of this channel evokes mitochondrial depolarization followed by mtROS production, which induces the activation of cell migration via MAPK activation. Microglial TRPV1 may play an important role in enhancing microglia accumulation at sites with abundant endovanilloids.

\section{Reference}

Aikawa R, Komuro I, Yamazaki T, Zou Y, Kudoh S, Tanaka M, Shiojima I, Hiroi Y, Yazaki Y. 1997. Oxidative stress activates extracellular signal-regulated kinases through Src and Ras in cultured cardiac myocytes of neonatal rats. J Clin Invest 100:1813-1821.

Basu S, Srivastava P. 2005. Immunological role of neuronal receptor vanilloid receptor 1 expressed on dendritic cells. Proc Natl Acad Sci U S A 102:5120-5125. 
Bertin S, Aoki-Nonaka Y, de Jong PR, Nohara LL, Xu H, Stanwood SR, Srikanth S, Lee J, To K, Abramson L, Yu T, Han T, Touma R, Li X, González-Navajas JM, Herdman S, Corr M, Fu G, Dong H, Gwack Y, Franco A, Jefferies WA, Raz E. 2014. The ion channel TRPV1 regulates the activation and proinflammatory properties of CD4+ T cells. Nat Immunol 15:1055-1063.

Bhatt NY, Kelley TW, Khramtsov VV, Wang Y, Lam GK, Clanton TL, Marsh CB. 2002. Macrophage-colony-stimulating factor-induced activation of extracellular-regulated kinase involves phosphatidylinositol 3-kinase and reactive oxygen species in human monocytes. J Immunol 169:6427-6434.

Black JA, Liu S, Waxman SG. 2009. Sodium channel activity modulates multiple functions in microglia. Glia 57:1072-1081.

Brookes PS, Yoon Y, Robotham JL, Anders MW, Sheu S. 2004. Calcium, ATP, and ROS: a mitochondrial love-hate triangle. Am J Physiol Cell Physiol 287:C817833.

Byrnes KR, Loane DJ, Faden AI. 2009. Metabotropic Glutamate Receptors as Targets for Multipotential Treatment of Neurological Disorders.

Neurotherapeutics 6:94-107.

Cardona AE, Pioro EP, Sasse ME, Kostenko V, Cardona SM, Dijkstra IM, Huang D, Kidd G, Dombrowski S, Dutta R, Lee JC, Cook DN, Jung S, Lira S, Littman DR, Ransohoff RM. 2006. Control of microglial neurotoxicity by the fractalkine receptor. Nat Neurosci 9:917-924.

Caterina MJ, Schumacher MA, Tominaga M, Rosen TA, Levine JD, Julius D. 1997. The capsaicin receptor: a heat-activated ion channel in the pain pathway. Nature 389:816-824.

Chávez AE, Chiu CQ, Castillo PE. 2010. TRPV1 activation by endogenous anandamide triggers postsynaptic long-term depression in dentate gyrus. Nat Neurosci 13:1511-1518.

Costa ADT, Garlid KD. 2008. Intramitochondrial signaling: interactions among mitoKatP, PKCe, ROS, and MPT. Am J Physiol Heart Circ Physiol 295:874-882.

Deluca HF, Engstrom GW. 1961. Calcium uptake by rat kidney mitochondria. Proc Natl Acad Sci U S A 47:1744-1750.

Fernandes ES, Liang L, Smillie SJ, Kaiser F, Purcell R, Rivett DW, Alam S, Howat S, Collins H, Thompson SJ, Keeble JE, Riffo-Vasquez Y, Bruce KD, Brain SD. 2012. TRPV1 deletion enhances local inflammation and accelerates the onset of systemic inflammatory response syndrome. J Immunol 188:5741-5751.

Ferraiuolo L, Kirby J, Grierson AJ, Sendtner M, Shaw PJ. 2011. Molecular pathways of motor neuron injury in amyotrophic lateral sclerosis. Nat Rev Neurol 7:616-630.

Franklin A, Parmentier-batteur S, Walter L, Greenberg DA, Stella N. 2003. Palmitoylethanolamide Increases after Focal Cerebral Ischemia and Potentiates Microglial Cell Motility. J Neurosci 23:7767-7775.

Gallego-Sandín S, Rodríguez-García A, Alonso MT, García-Sancho J. 2009. The endoplasmic reticulum of dorsal root ganglion neurons contains functional TRPV1 channels. J Biol Chem 284:32591-32601. 
Grueter BA, Brasnjo G, Malenka RC. 2010. Postsynaptic TRPV1 triggers cell type-specific long-term depression in the nucleus accumbens. Nat Neurosci 13:1519-1525.

Guyton KZ, Liu Y, Gorospe M, Xu Q, Holbrook NJ. 1996. Activation of Mitogen activated Protein Kinase by $\mathrm{H}_{2} \mathrm{O}_{2}$. Role in cell survival following oxidant injury. J Biol Chem 271:4138-4142.

Hanisch UK, Kettenmann H. 2007. Microglia: active sensor and versatile effector cells in the normal and pathologic brain. Nat Neurosci 10:1387-1394.

Hassan S, Eldeeb K, Millns PJ, Bennett AJ, Alexander SP, Kendall DA. 2014. Cannabidiol enhances microglial phagocytosis via transient receptor potential (TRP) channel activation. Br J Pharmacol 171:2426-2439.

Ho KW, Lambert WS, Calkins DJ. 2014. Activation of the TRPV1 cation channel contributes to stress-induced astrocyte migration. Glia 62:1435-1451.

Honda S, Sasaki Y, Ohsawa K, Imai Y, Nakamura Y, Inoue K, Kohsaka S. 2001. Extracellular ATP or ADP induce chemotaxis of cultured microglia through

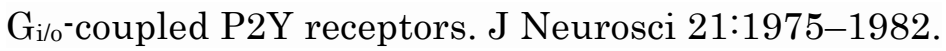

Hwang SW, Cho H, Kwak J, Lee S, Kang C, Jung J, Cho S, Min KH, Suh Y, Kim D, Oh U. 2000. Direct activation of capsaicin receptors by products of lipoxygenases: Endogenous capsaicin-like substances. Proc Natl Acad Sci U S A 97:6155-6160.

Ikeda S, Yamaoka-Tojo M, Hilenski L, Patrushev N a, Anwar GM, Quinn MT, Ushio-Fukai M. 2005. IQGAP1 regulates reactive oxygen species-dependent endothelial cell migration through interacting with Nox2. Arterioscler Thromb Vasc Biol 25:2295-2300.

Ito N, Ruegg U, Kudo A. 2013. Activation of calcium signaling through Trpv1 by nNOS and peroxynitrite as a key trigger of skeletal muscle hypertrophy. Nat Med 19:101-106.

Jiang S, Park DW, Stigler WS, Creighton J, Ravi S, Darley-Usmar V, Zmijewski JW. 2013. Mitochondria and AMP-activated protein kinase-dependent mechanism of efferocytosis. J Biol Chem 288:26013-26026.

Kettenmann H, Hanisch U-K, Noda M, Verkhratsky A. 2011. Physiology of microglia. Physiol Rev 91:461-553.

Kim SR, Kim SU, Oh U, Jin BK. 2006. Transient receptor potential vanilloid subtype 1 mediates microglial cell death in vivo and in vitro via $\mathrm{Ca}^{2+}$-mediated mitochondrial damage and cytochrome c release. J Immunol 177:4322-4329.

Kim HS, Kwon HJ, Kim GE, Cho MH, Yoon SY, Davies AJ, Oh SB, Lee H, Cho YK, Joo CH, Kwon SW, Kim SC, Kim YK. 2014. Attenuation of natural killer cell functions by capsaicin through a direct and TRPV1-independent mechanism. Carcinogenesis 35:1652-1660.

Kim HS, Ullevig SL, Zamora D, Lee CF, Asmis R. 2012. Redox regulation of MAPK phosphatase 1 controls monocyte migration and macrophage recruitment. Proc Natl Acad Sci U S A 109:E2803-2812.

Klyubin IV, Kirpichnikova KM, Gamaley IA. 1996. Hydrogen peroxide-induced chemotaxis of mouse peritoneal neutrophils. Eur J Cell Biol 70:347-351. 
Koizumi S, Ohsawa K, Inoue K, Kohsaka S. 2013. Purinergic receptors in microglia: functional modal shifts of microglia mediated by $\mathrm{P} 2$ and $\mathrm{P} 1$ receptors. Glia 61:47-54.

Konno M, Shirakawa H, Iida S, Sakimoto S, Matsutani I, Miyake T, Kageyama K, Nakagawa T, Shibasaki K, Kaneko S. 2012. Stimulation of transient receptor potential vanilloid 4 channel suppresses abnormal activation of microglia induced by lipopolysaccharide. Glia 60:761-770.

Kuenzi FM, Dale N. 1996. Effect of capsaicin and analogues on potassium and calcium currents and vanilloid receptors in Xenopus embryo spinal neurones. $\mathrm{Br}$ J Pharmacol 119:81-90.

Lang H, Li Q, Yu H, Li P, Lu Z, Xiong S, Yang T, Zhao Y, Huang X, Gao P, Zhang H, Shang Q, Liu D, Zhu Z. 2014. Activation of TRPV1 attenuates high salt induced cardiac hypertrophy through improvement of mitochondrial function. Br J Pharmacol in press. DOI: 10.1111/bph.12987.

Li X, Fang P, Mai J, Choi ET, Wang H, Yang X. 2013. Targeting mitochondrial reactive oxygen species as novel therapy for inflammatory diseases and cancers. J Hematol Oncol 6:19.

Liang KJ, Lee JE, Wang YD, Ma W, Fontainhas AM, Fariss RN, Wong WT. 2009. Regulation of dynamic behavior of retinal microglia by $\mathrm{CX}_{3} \mathrm{CR} 1$ signaling. Invest Ophthalmol Vis Sci 50:4444-4451.

Liu GJ, Nagarajah R, Banati RB, Bennett MR. 2009. Glutamate induces directed chemotaxis of microglia. Eur J Neurosci 29:1108-1118.

Liu WH, Cheng YC, Chang LS. 2009. ROS-mediated p38alpha MAPK activation and ERK inactivation responsible for upregulation of Fas and FasL and autocrine Fas mediated cell death in Taiwan cobra phospholipase $\mathrm{A}_{2}$-treated U937 cells. J Cell Physiol 219:642-651.

Loo AEK, Ho R, Halliwell B. 2011. Mechanism of hydrogen peroxide-induced keratinocyte migration in a scratch-wound model. Free Radic Biol Med 51:884892.

Maccarrone M, Rossi S, Bari M, De Chiara V, Fezza F, Musella A, Gasperi V, Prosperetti C, Bernardi G, Finazzi-Agrò A, Cravatt BF, Centonze D. 2008. Anandamide inhibits metabolism and physiological actions of 2-arachidonoylglycerol in the striatum. Nat Neurosci 11:152-159.

Mannari T, Morita S, Furube E, Tominaga M, Miyata S. 2013. Astrocytic TRPV1 ion channels detect blood-borne signals in the sensory circumventricular organs of adult mouse brains. Glia 61:957-971.

Marsicano G, Goodenough S, Monory K, Hermann H, Eder M, Cannich A, Azad SC, Cascio MG, Gutiérrez SO, van der Stelt M, López-Rodriguez ML, Casanova E, Schütz G, Zieglgänsberger W, Di Marzo V, Behl C, Lutz B. 2003. CB1 cannabinoid receptors and on-demand defense against excitotoxicity. Science 302:84-88.

Miyake T, Shirakawa H, Kusano A, Sakimoto S, Konno M, Nakagawa T, Mori Y, Kaneko S. 2014. TRPM2 contributes to LPS/IFNY-induced production of nitric oxide via the p38/JNK pathway in microglia. Biochem Biophys Res Commun 444:212-217. 
Mizoguchi Y, Kato TA, Seki Y, Ohgidani M, Sagata N, Horikawa H, Yamauchi Y, Sato-Kasai M, Hayakawa K, Inoue R, Kanba S, Monji A. 2014. Brain-derived neurotrophic factor (BDNF) induces sustained intracellular $\mathrm{Ca}^{2+}$ elevation through the up-regulation of surface transient receptor potential 3 (TRPC3) channels in rodent microglia. J Biol Chem 289:212-217.

Moreira S, Stramer B, Evans I, Wood W, Martin P. 2010. Prioritization of competing damage and developmental signals by migrating macrophages in the Drosophila embryo. Curr Biol 20:464-470.

Muessel MJ, Harry GJ, Armstrong DL, Storey NM. 2013. SDF-1a and LPA modulate microglia potassium channels through rho gtpases to regulate cell morphology. Glia 61:1620-1628.

Navarrete M, Araque A. 2010. Endocannabinoids potentiate synaptic transmission through stimulation of astrocytes. Neuron 68:113-126.

Niethammer P, Grabher C, Look AT, Mitchison TJ. 2009. A tissue-scale gradient of hydrogen peroxide mediates rapid wound detection in zebrafish. Nature 459:996-999.

Nimnual AS, Taylor LJ, Bar-Sagi D. 2003. Redox-dependent downregulation of Rho by Rac. Nat Cell Biol 5:236-241.

Nishida M, Maruyama Y, Tanaka R, Kontani K, Nagao T, Kurose H. 2000. Gai and $\mathrm{G}_{\text {ао }}$ are target proteins of reactive oxygen species. Nature 408:492-495.

Numazaki M, Tominaga T, Toyooka H, Tominaga M. 2002. Direct phosphorylation of capsaicin receptor VR1 by protein kinase $\mathrm{C} \varepsilon$ and identification of two target serine residues. J Biol Chem 277:13375-13378.

Ogura M, Kitamura M. 1998. Oxidant stress incites spreading of macrophages via extracellular signal-regulated kinases and p38 mitogen-activated protein kinase. J Immunol 161:3569-3574.

Ohsawa K, Irino Y, Nakamura Y, Akazawa C, Inoue K. 2007. Involvement of P2X and $\mathrm{P}_{2} \mathrm{Y}_{12}$ receptors in ATP-induced microglial chemotaxis. Glia 55:604-616.

Panikashvili D, Simeonidou C, Ben-Shabat S, Hanus L, Breuer A, Mechoulam R, Shohami E. 2001. An endogenous cannabinoid (2-AG) is neuroprotective after brain injury. Nature 413:527-531.

Park ES, Kim SR Jing BK. 2012. Transient receptor potential vanilloid subtype 1 contributes to mesencephalic dopaminergic neuronal survival by inhibiting microglia-originated oxidative stress. Brain Res Bull 89:92-96.

Park J, Choi H, Min JS, Park SJ, Kim JH, Park HJ, Kim B, Chae JI, Yim M, Lee DS. 2013. Mitochondrial dynamics modulate the expression of pro-inflammatory mediators in microglial cells. J Neurochem 127:221-232.

Ristoiu V, Shibasaki K, Uchida K, Zhou Y, Ton BHT, Flonta ML, Tominaga M. 2011. Hypoxia-induced sensitization of transient receptor potential vanilloid 1 involves activation of hypoxia-inducible factor-1 alpha and PKC. Pain 152:936945.

Rizzuto R, De Stefani D, Raffaello A, Mammucari C. 2012. Mitochondria as sensors and regulators of calcium signalling. Nat Rev Mol Cell Biol 13:566-578.

Sappington R, Calkins D. 2008. Contribution of TRPV1 to microglia-derived IL-6 and $\mathrm{NFkB}$ translocation with elevated hydrostatic pressure. Invest Ophthalmol Vis Sci 49:3004-3017. 
Schilling T, Eder C. 2009. Non-selective cation channel activity is required for lysophosphatidylcholine-induced monocyte migration. J Cell Physiol 221:325334 .

Schilling T, Eder C. 2011. Amyloid-B-induced reactive oxygen species production and priming are differentially regulated by ion channels in microglia. J Cell Physiol 226:3295-3302.

Shirakawa H, Sakimoto S, Nakao K, Sugishita A, Konno M, Iida S, Kusano A, Hashimoto E, Nakagawa T, Kaneko S. 2010. Transient receptor potential canonical 3 (TRPC3) mediates thrombin-induced astrocyte activation and upregulates its own expression in cortical astrocytes. J Neurosci 30:1311613129.

Siddiqui TA, Lively S, Vincent C, Schlichter Vincent C, Schlichter LC. 2012. Regulation of podosome formation, microglial migration and invasion by $\mathrm{Ca}^{2+-}$ signaling molecules expressed in podosomes. J Neuroinflammation 9:250.

Stock K, Kumar J, Synowitz M, Petrosino S, Imperatore R, Smith E St J, Wend P, Purfürst B, Nuber U, Gurok U, Matyash V, Wälzlein JH, Chirasani SR, Dittmar G, Cravatt BF, Momma S, Lewin GR, Ligresti A, De Petrocellis L, Cristino L, Di Marzo V, Kettenmann H, Glass R. 2012. Neural precursor cells induce cell death of high-grade astrocytomas through stimulation of TRPV1. Nat Med 18:12321239 .

Takeuchi A, Kim B, Matsuoka S. 2014. The destiny of $\mathrm{Ca}^{2+}$ released by mitochondria. J Physiol Sci in press.

Tanimura A, Yamazaki M, Hashimotodani Y, Uchigashima M, Kawata S, Abe M, Kita Y, Hashimoto K, Shimizu T, Watanabe M, Sakimura K, Kano M. 2010. The endocannabinoid 2-arachidonoylglycerol produced by diacylglycerol lipase alpha mediates retrograde suppression of synaptic transmission. Neuron 65:320-327.

Tominaga M, Caterina MJ, Malmberg AB, Rosen TA, Gilbert H, Skinner K, Raumann BE, Basbaum AI, Julius D. 1998. The Cloned Capsaicin Receptor Integrates Multiple Pain-Producing Stimuli. Neuron 21:531-543.

Turner H, Fleig A, Stokes A, Kinet J, Penner R. 2003. Discrimination of intracellular calcium store subcompartments using TRPV1 (transient receptor potential channel, vanilloid subfamily member 1) release channel activity. Biochem J 371:341-350.

Vasington FD, Murphy JV. 1962. $\mathrm{Ca}^{++}$ion uptake by rat kidney mitochondria and its dependence on respiration and phosphorylation. J Biol Chem 237:2670-2677.

Walter L, Franklin A, Witting A, Wade C, Xie Y, Kunos G, Mackie K, Stella N. 2003. Nonpsychotropic Cannabinoid Receptors Regulate Microglial Cell Migration. J Neurosci 23:1398-1405.

Wang Y, Zang QS, Liu Z, Wu Q, Maass D, Dulan G, Shaul PW, Melito L, Frantz DE, Kilgore J a, Williams NS, Terada LS, Nwariaku FE. 2011. Regulation of VEGF-induced endothelial cell migration by mitochondrial reactive oxygen species. Am J Physiol Cell Physiol 301:C695-704.

Wu L, Sweet T, Clapham D. 2010. International Union of Basic and Clinical Pharmacology. LXXVI. Current progress in the mammalian TRP ion channel family. Pharmacol Rev 62:381-404. 
Yang R, Xiong Z, Liu C, Liu L. 2014. Inhibitory effects of capsaicin on voltage-gated potassium channels by TRPV1-independent pathway. Cell Mol Neurobiol 34: $565-576$.

Yu XW, Hu ZL, Ni M, Fang P, Zhang PW, Shu Q, Fan H, Zhou HY, Ni L, Zhu LQ, Chen JG, Wang F. 2015. Acid-sensing ion channels promote the inflammation and migration of cultured rat microglia. Glia 63:483-496.

Zygmunt PM, Petersson J, Andersson DA, Chuang H, Sørgård M, Di Marzo V, Julius D, Högestätt ED. 1999. Vanilloid receptors on sensory nerves mediate the vasodilator action of anandamide. Nature 400:452-457.

Zygmunt PM, Ermund A, Movahed P, Andersson DA, Simonsen C, Jönsson BA, Blomgren A, Birnir B, Bevan S, Eschalier A, Mallet C, Gomis A, Högestätt ED. 2013. Monoacylglycerols activate TRPV1 -- a link between phospholipase C and TRPV1. PLoS One 8:e81618.

\section{Figure legends}

Figure 1.

TRPV1 activation enhances chemotactic activity in cultured murine microglia. A-B, Chemotactic activity of microglia from wild-type (A) or TRPV1-KO (B) mice induced by capsaicin $(1-10 \mu \mathrm{M})$ with or without SB366791 $(3 \mu \mathrm{M})$ or BAPTA-AM $(10 \mu \mathrm{M})$ was quantitated with the chemotactic assay as described in the Materials and Methods. Data are presented as means with SEM. ** $p<0.01 ; * * * p<0.001$ vs. non-treated; \#\#p<0.01; \# $<0.001$ vs. $10 \mu \mathrm{M}$ capsaicin treated; $n=4-8$. C, Microglial cultures were scratched as described in the Materials and Methods, and phase contrast images were acquired with low magnification at $0 \mathrm{~h}$ (left) and after $24 \mathrm{~h}$ (right) with or without capsaicin $(10 \mu \mathrm{M})$. Dotted lines represent the initial position of the microglia. Note that the number of the microglia invading the wound is increased. D-E, Microglia from wild-type (D) or TRPV1-KO (E) mice were plated on coverslips and treated with or without capsaicin (CAP, $10 \mu \mathrm{M})$ and/or the TRPV1 selective blocker SB366791 (SB, $3 \mu \mathrm{M})$. After $24 \mathrm{~h}$, cells were fixed and stained with DAPI and Alexa Fluor 488-conjugated phalloidin to visualize nuclei and actin filaments. White arrows indicate membrane ruffles, signifying migrating cells. Scale bar: $30 \mu \mathrm{m}$.

Figure 2.

TRPV1 activation is not involved in additional microglial functions. A-B, ATP (100 $\mu \mathrm{M}$ )-induced chemotactic activity of wild-type (A) or TRPV1-KO (B) microglia was quantified with the chemotactic assay as described in the Materials and Methods. $* * * p<0.001$ vs. control (Cont.); $n=4$. C-H, Microglial cultures were treated with or without capsaicin $(10 \mu \mathrm{M})$ in addition to LPS $(100 \mathrm{ng} / \mathrm{mL})$ and $\operatorname{IFN} \gamma(10 \mathrm{ng} / \mathrm{mL})$ (LPS/IFN $\gamma$ ) for $48 \mathrm{~h}$. The concentration of NO in the media of wild-type (C) or TRPV1-KO (D) cultures was determined using the Griess reaction. The concentrations of TNF- $\alpha(\mathrm{E}, \mathrm{F})$ and IL- $6(\mathrm{G}, \mathrm{H})$ in the supernatants of wild-type (E, $\mathrm{G})$ or TRPV1-KO $(\mathrm{F}, \mathrm{H})$ cultures were determined with an ELISA. Data are 
presented as means with SEM. ${ }^{* * *} p<0.001$ vs. Cont., \#p $<0.001$ vs. $10 \mu \mathrm{M}$ capsaicin treated; $n=4-5$.

Figure 3.

TRPV1 is expressed intracellularly in microglia. A, HEK293T cells stably expressing rTRPV1 (upper) or microglia derived from wild-type (middle) or TRPV1-KO (lower) mice were plated on coverslips, fixed, and immunostained with TRPV1 antibody. Scale bar: $10 \mu \mathrm{m}$. B, same as A, but cells were stained with DAPI in addition to anti-TRPV1 antibody and examined at low-magnification. Scale bar: $50 \mu \mathrm{m}$. C, Microglia were plated on coverslips, fixed, and immunostained or stained with TRPV1 antibody (green) and organelle markers (ER, calregulin; lysosome, Lamp1; Golgi, 58K Golgi protein; mitochondria, MitoTracker Red) (red). Magnified pictures are higher magnification of the boxed areas in merged pictures. Scale bar: $10 \mu \mathrm{m}$ (Merge) or $1 \mu \mathrm{m}$ (Magnified).

Figure 4.

Functional TRPV1 is located on mitochondria in microglia. A-C, HEK293T cells transiently expressing rTRPV1 (A) or wild-type microglia (B-C) were plated on coverslips and whole-cell recording (A-B, left, time course; right, current-voltage relationship) or Fura-2 intracellular $\mathrm{Ca}^{2+}$ imaging (C, $n=100$ cells) was performed, where $\mathrm{Ca}^{2+}$ ionophore ionomycin at $3 \mu \mathrm{M}$ was used to elicit maximum $\mathrm{Ca} 2+$ responses. D-E, Microglia derived from wild-type or TRPV1-KO mice were plated on glass-bottom dishes and Rhod-5N intramitochondrial $\mathrm{Ca}^{2+}$ imaging was performed. Representative averaged curves with error bars (SEM) are shown in D (wild-type, $n=104$ ROI; TRPV1-KO, $n=98 \mathrm{ROI}$ ), and E represents statistical analysis of mitochondrial $\mathrm{Ca}^{2+}$ influx induced by capsaicin $(10 \mu \mathrm{M}) .{ }^{*} p<0.05 \mathrm{vs}$. wild-type; $n=3-4$. F-H, Microglia derived from wild-type or TRPV1-KO mice were plated on coverslips, and Fura-2 intracellular $\mathrm{Ca}^{2+}$ imaging was performed in the presence or absence of SB366791 $(3 \mu \mathrm{M})$. Representative averaged curves with error bars (SEM) are shown in F (wild-type, $n=85$ cells; wild-type + SB366791, $\mathrm{n}=$ 82 cells; TRPV1-KO, $n=92$ cells), and G-H represent statistical analyses of amplitudes $(\mathrm{G})$ and times to half-amplitude $(\mathrm{H})$ of the $10 \mu \mathrm{M}$ ATP-evoked responses. ${ }^{*} p<0.05$ vs. wild-type; $n=7-9$. I-J, Microglia derived from wild-type (I) or TRPV1-KO (J) mice were plated on glass-bottom dishes and treated with or without capsaicin $(10 \mu \mathrm{M})$ and/or SB366791 $(3 \mu \mathrm{M})$. After $24 \mathrm{~h}$, changes in the mitochondrial membrane potential were detected using the JC-1 assay as described in the Materials and Methods. ${ }^{* *} p<0.01$ vs. control (Cont.); $n=4-5$. Data are presented as means with SEM.

Figure 5.

Capsaicin-induced chemotaxis is mediated by mitochondrial ROS, p38 MAPK, and JNK. A, Chemotactic activity of wild-type microglia in the presence of rotenone (0.3 $\mu \mathrm{M})$ was quantitated with the chemotactic assay as described in the Materials and Methods. Note that ATP $(100 \mu \mathrm{M})$ significantly induced chemotaxis even in the presence of rotenone. n.s., not significant; ${ }^{*} p<0.01 ; n=4-8$. B, The effect of antioxidants (see Results for details) on the $10 \mu \mathrm{M}$ capsaicin-induced chemotactic 
activity of wild-type microglia was quantitated with the chemotactic assay. ${ }^{* * *} p<$ 0.001 vs. control (Cont.); $\# p<0.05 ; \# \#<0.001$ vs. $10 \mu \mathrm{M}$ capsaicin treated; $n=4$. C-D, Chemotactic activity of microglia derived from wild-type (C) or TRPV1-KO (D) mice induced by $\mathrm{H}_{2} \mathrm{O}_{2}(10 \mu \mathrm{M})$ with or without SB366791 $(3 \mu \mathrm{M})$, EUK-134 $(3 \mu \mathrm{M})$, PD98059 $(10 \mu \mathrm{M})$, SB203580 $(30 \mu \mathrm{M})$, or SP600125 $(30 \mu \mathrm{M})$ was quantitated with the chemotactic assay. ${ }^{*} p<0.05 ;{ }^{* * *} p<0.001$ vs. Cont.; \# $p<0.01, \# \# p<0.001$ vs. $10 \mu \mathrm{M} \mathrm{H}_{2} \mathrm{O}_{2}$ treated; $n=8-16$. E, Chemotactic activity of wild-type microglia induced by capsaicin $(10 \mu \mathrm{M})$ in the presence of PD98059 $(10 \mu \mathrm{M})$, SB203580 (30 $\mu \mathrm{M})$, or SP600125 $(30 \mu \mathrm{M})$ was quantitated with the chemotactic assay. ${ }^{*} p<0.05$ vs. Cont.; $p<0.01$ vs. $10 \mu \mathrm{M}$ capsaicin treated; $n=4$. All data are presented as means with SEM.

Figure 6.

Endovanilloids enhance chemotactic activity via TRPV1 activation in microglia. A$\mathrm{B}$, Chemotactic activity of microglia derived from wild-type (A) or TRPV1-KO (B) mice induced by a mixture of endovanilloids (AEA $[30 \mu \mathrm{M}]+$ OEA $[1 \mu \mathrm{M}]+$ PEA $[1$ $\mu \mathrm{M}])$ with or without EUK-134 $(3 \mu \mathrm{M})$ was quantitated with the chemotactic assay. $* * p<0.01$ vs. control (Cont.); $\# p<0.05$ vs. treatment with the mixture of endovanilloids; $n=4$. C-D, Wild-type (C) or TRPV1-KO (D) microglia were plated on glass-bottom dishes and treated with or without the mixture of endovanilloids (same as A-B) with or without SB366791 $(3 \mu \mathrm{M})$. After $24 \mathrm{~h}$, changes in the mitochondrial membrane potential were detected using the $\mathrm{JC}-1$ assay as described in the Materials and Methods. ${ }^{*} p<0.05$ vs. Cont.; \#p<0 0.01 vs. treatment with the mixture of endovanilloids; $n=4-5$. All data are presented as means with SEM. 

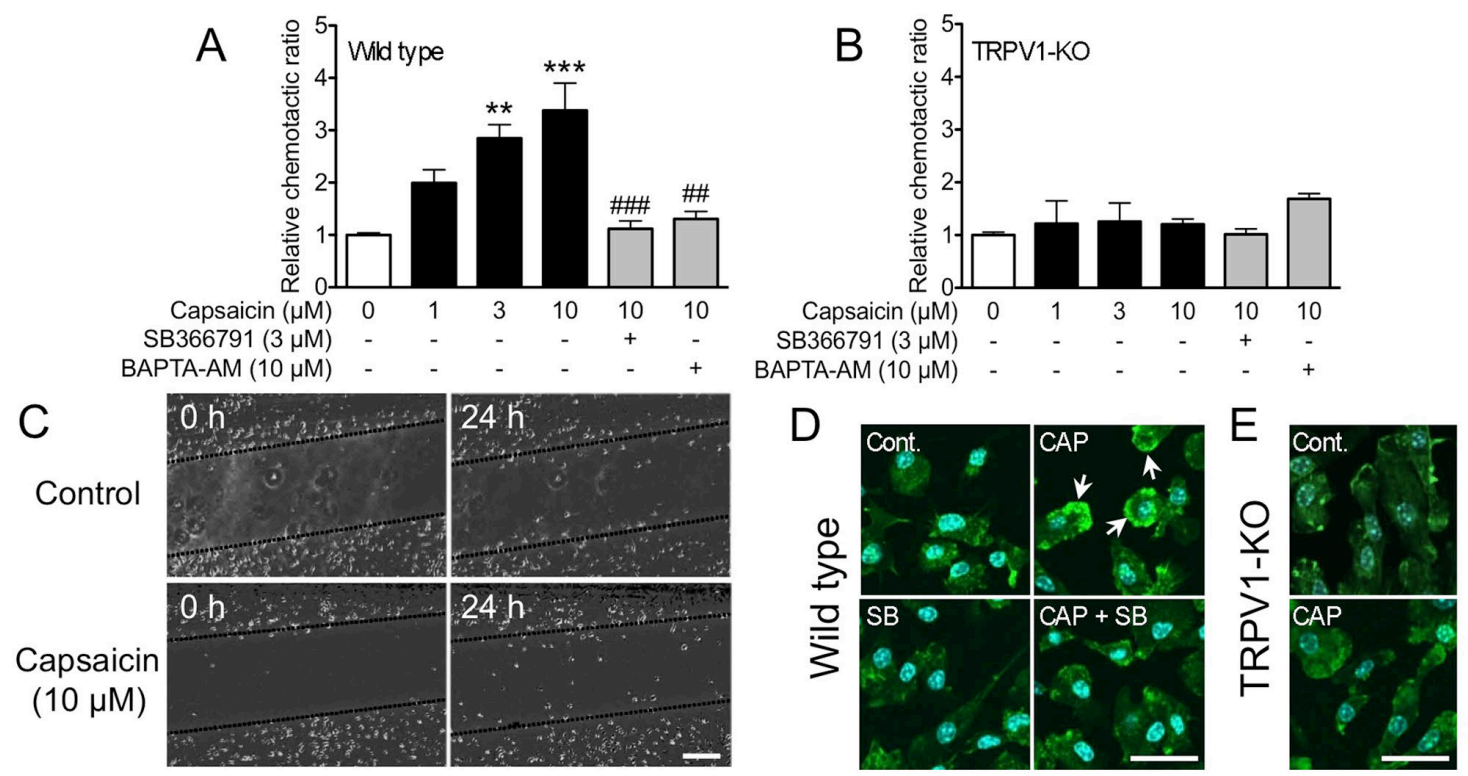

Miyake et al., 2015, Figure 1 
A

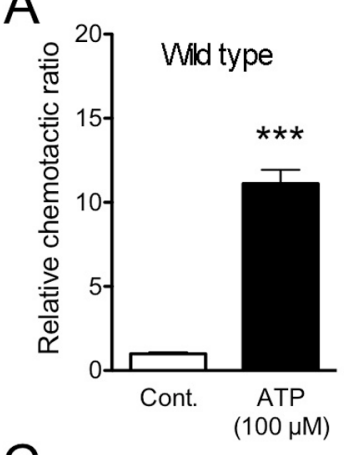

C

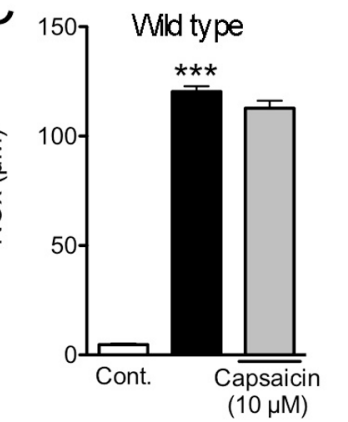

E $\quad \begin{array}{ll}\mathrm{LPS}(100 \mathrm{ng} / \mathrm{mL}) \\ +\mathrm{IFN \gamma}(10 \mathrm{ng} / \mathrm{mL})\end{array}$

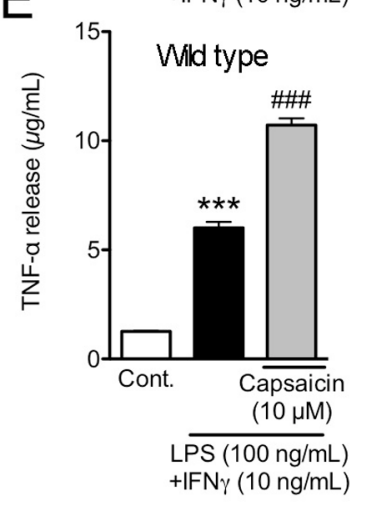

G

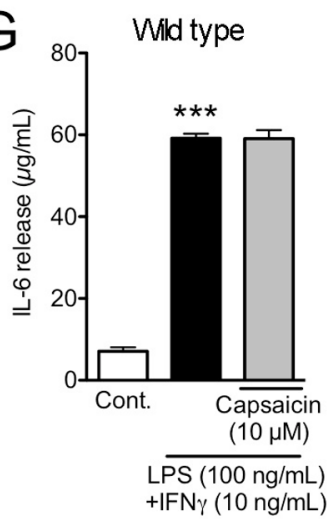

B

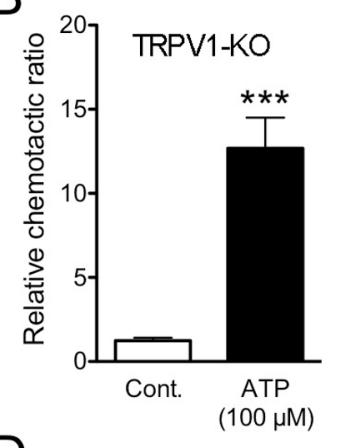

D ${ }_{150}$ TRPV1-KO
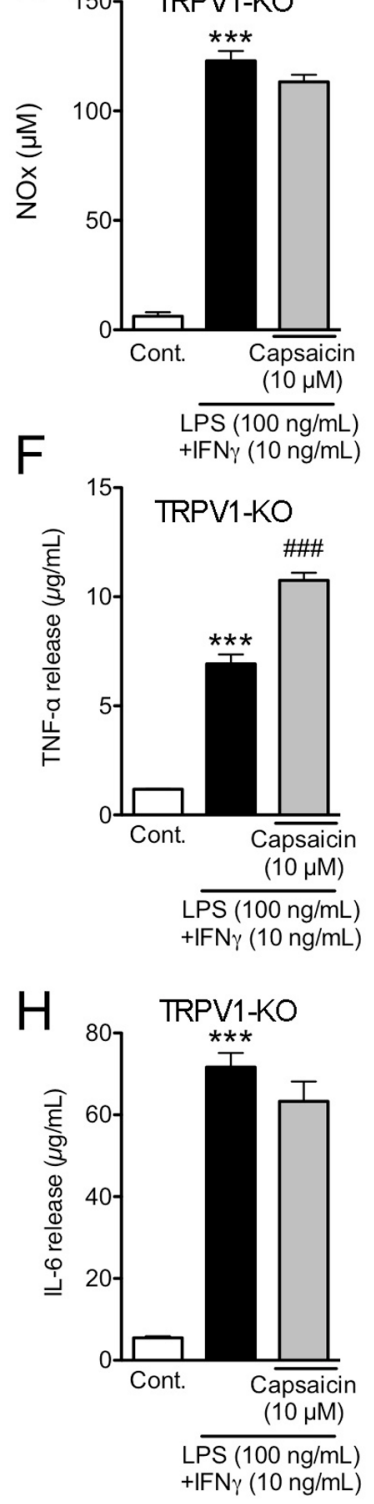

Miyake et al., 2015, Figure 2 


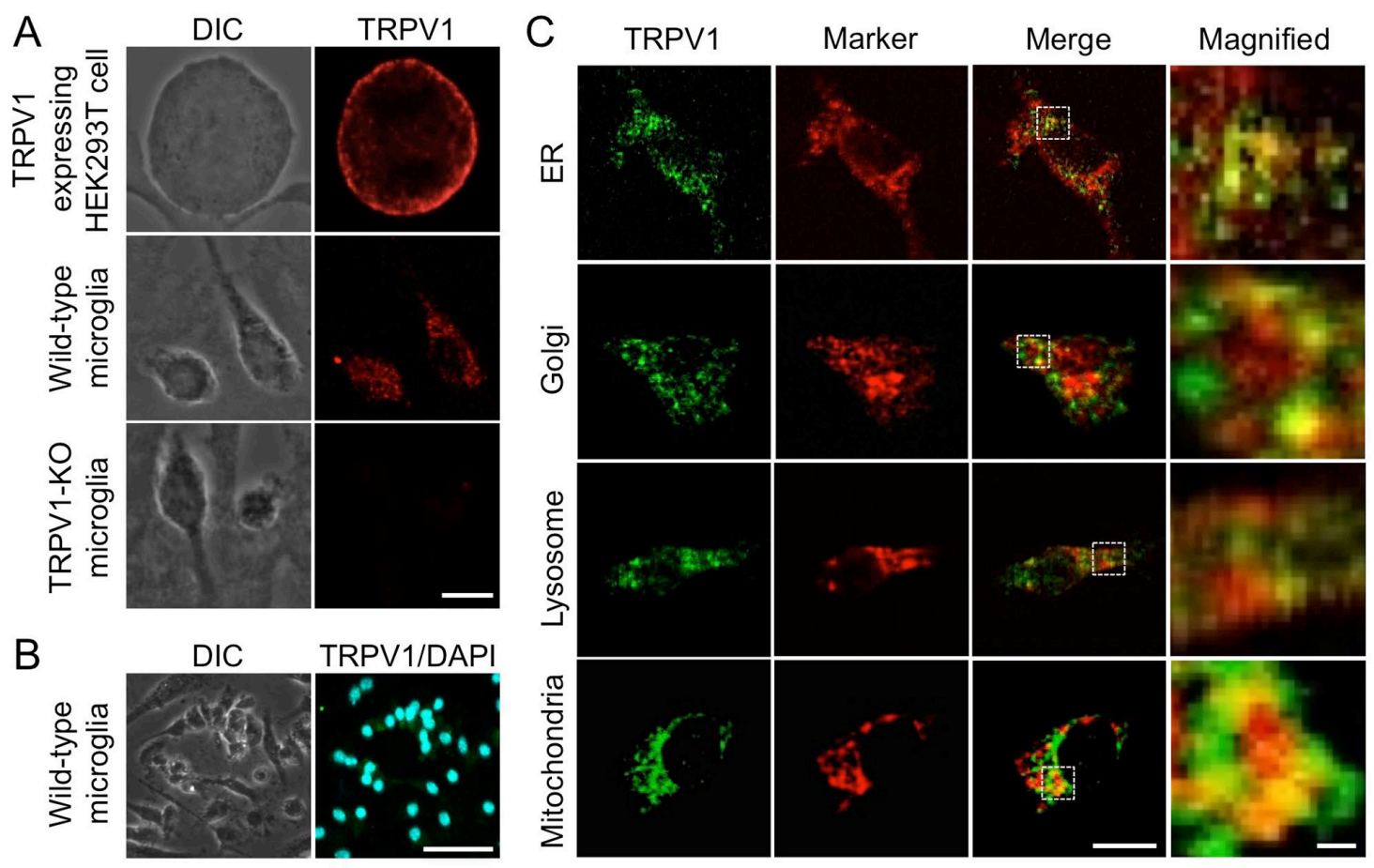

Miyake et al., 2015, Figure 3 
A TRPV1-expressing HEK293T cell
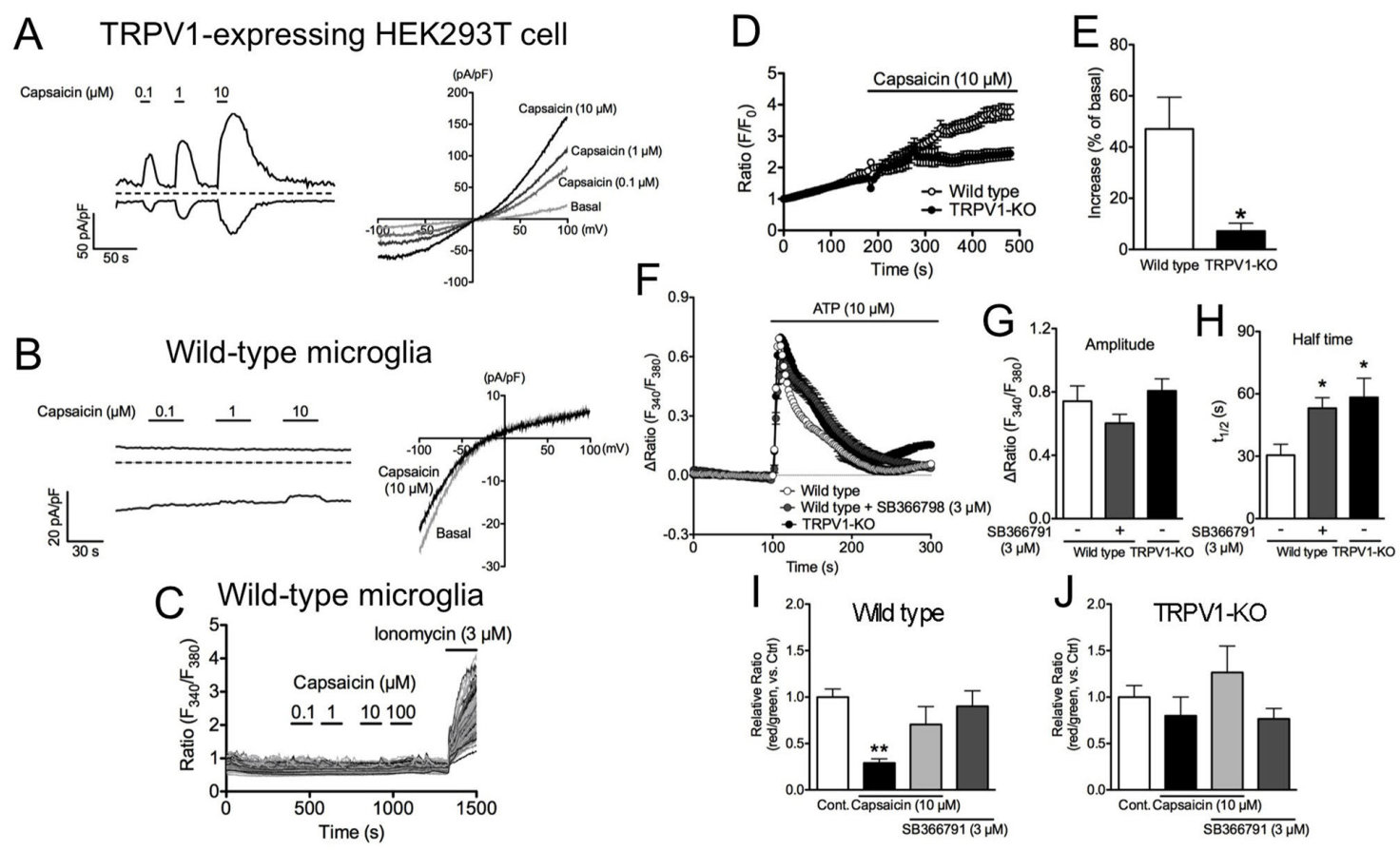

Miyake et al., 2015, Figure 4 

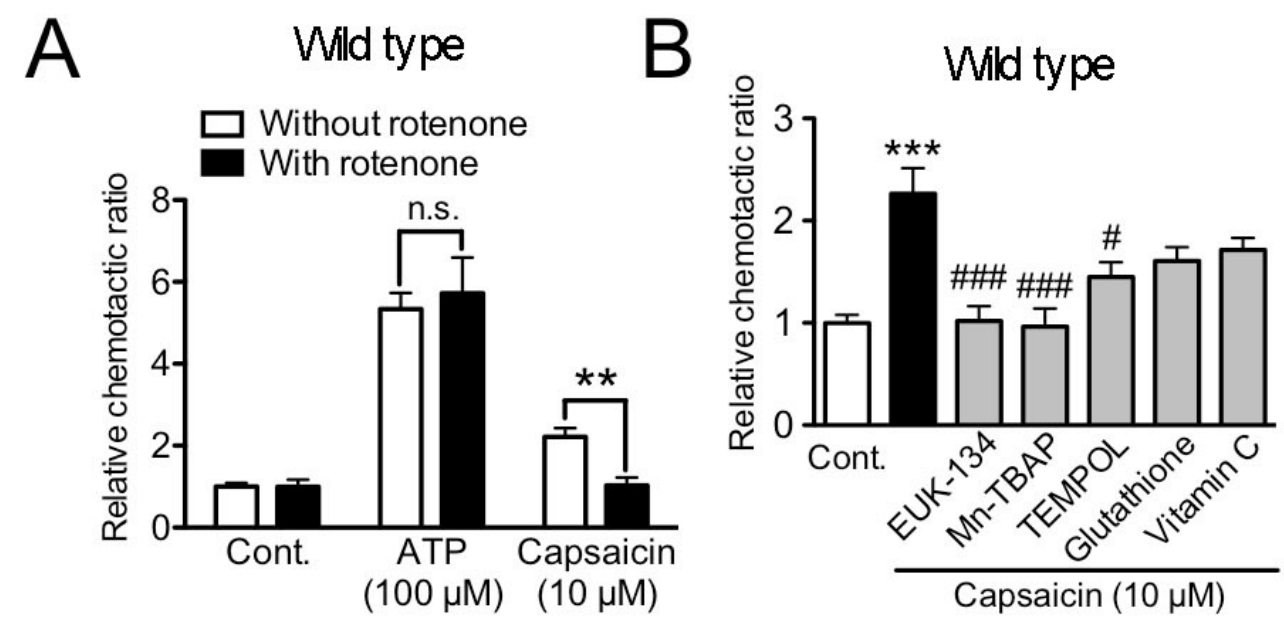

C

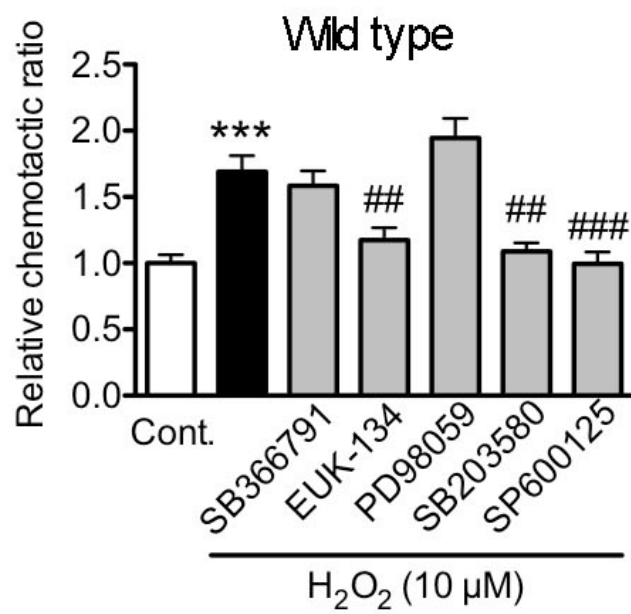

D
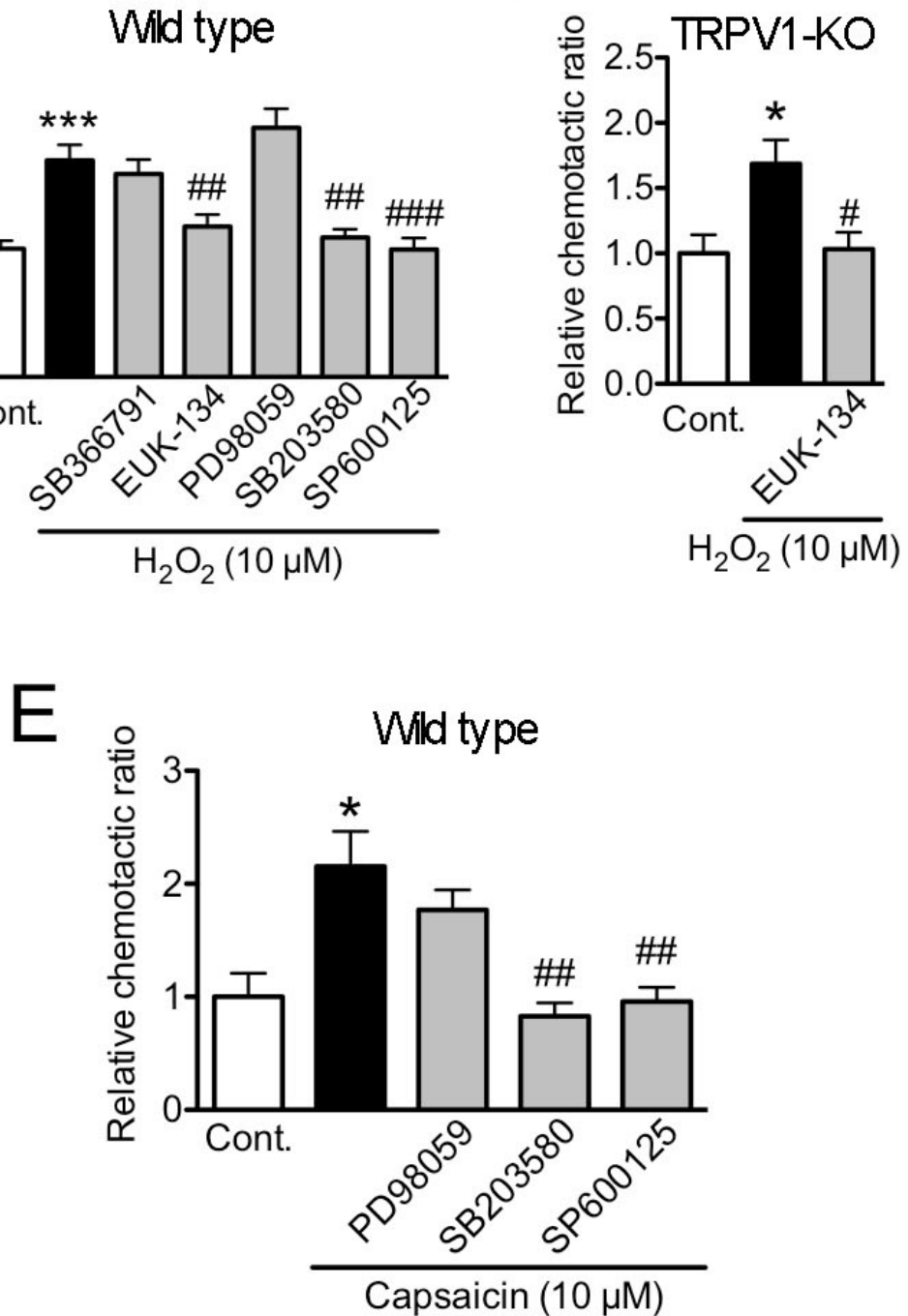

Miyake et al., 2015, Figure 5 


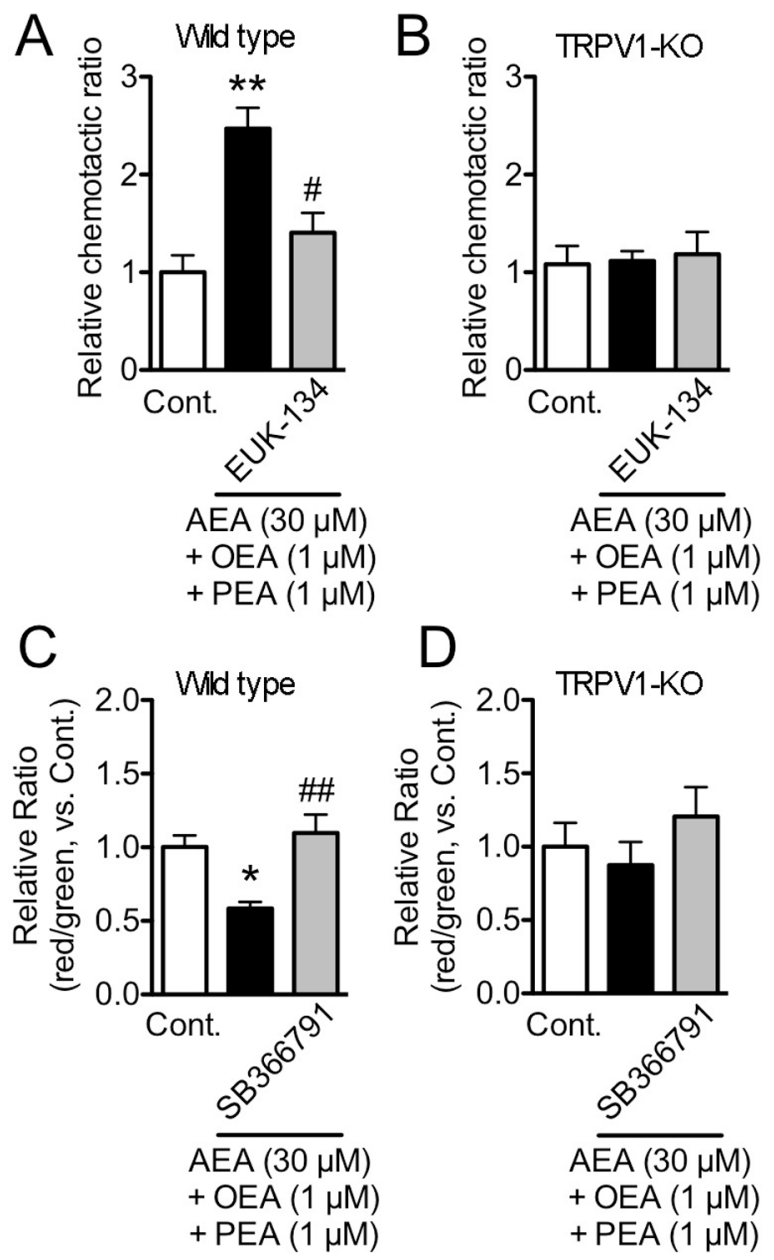

Miyake et al., 2015, Figure 6 

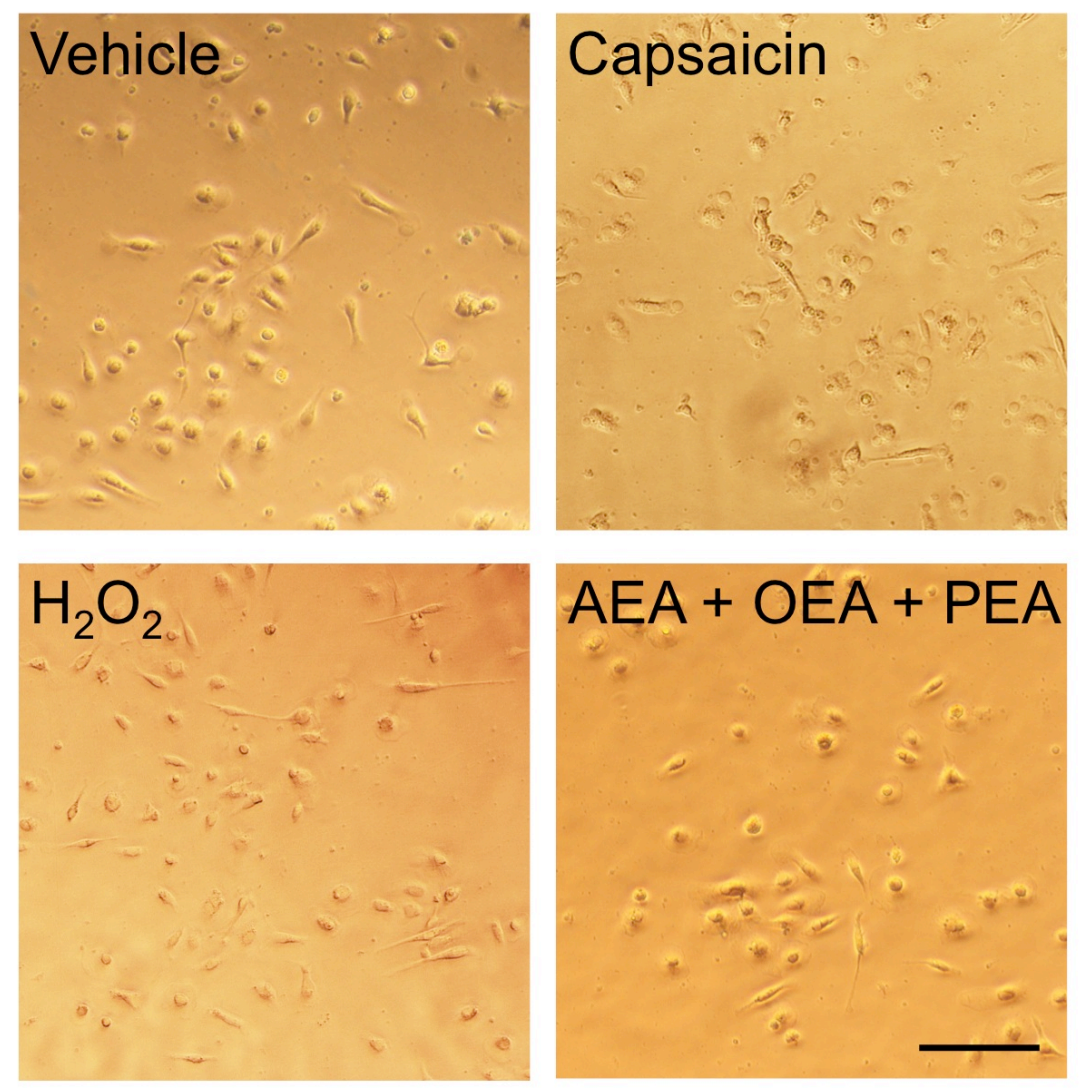

Miyake et al., 2015, Supplemental information Fig. S1

Wild-type microglia were treated with vehicle, capsaicin $(10 \mu \mathrm{M}), \mathrm{H}_{2} \mathrm{O}_{2}(10$ $\mu \mathrm{M})$ or AEA $(30 \mu \mathrm{M})+$ OEA $(1 \mu \mathrm{M})+$ PEA $(1 \mu \mathrm{M})$ for $24 \mathrm{~h}$ and afterward the morphology was observed. Scale bar: $100 \mu \mathrm{m}$. 


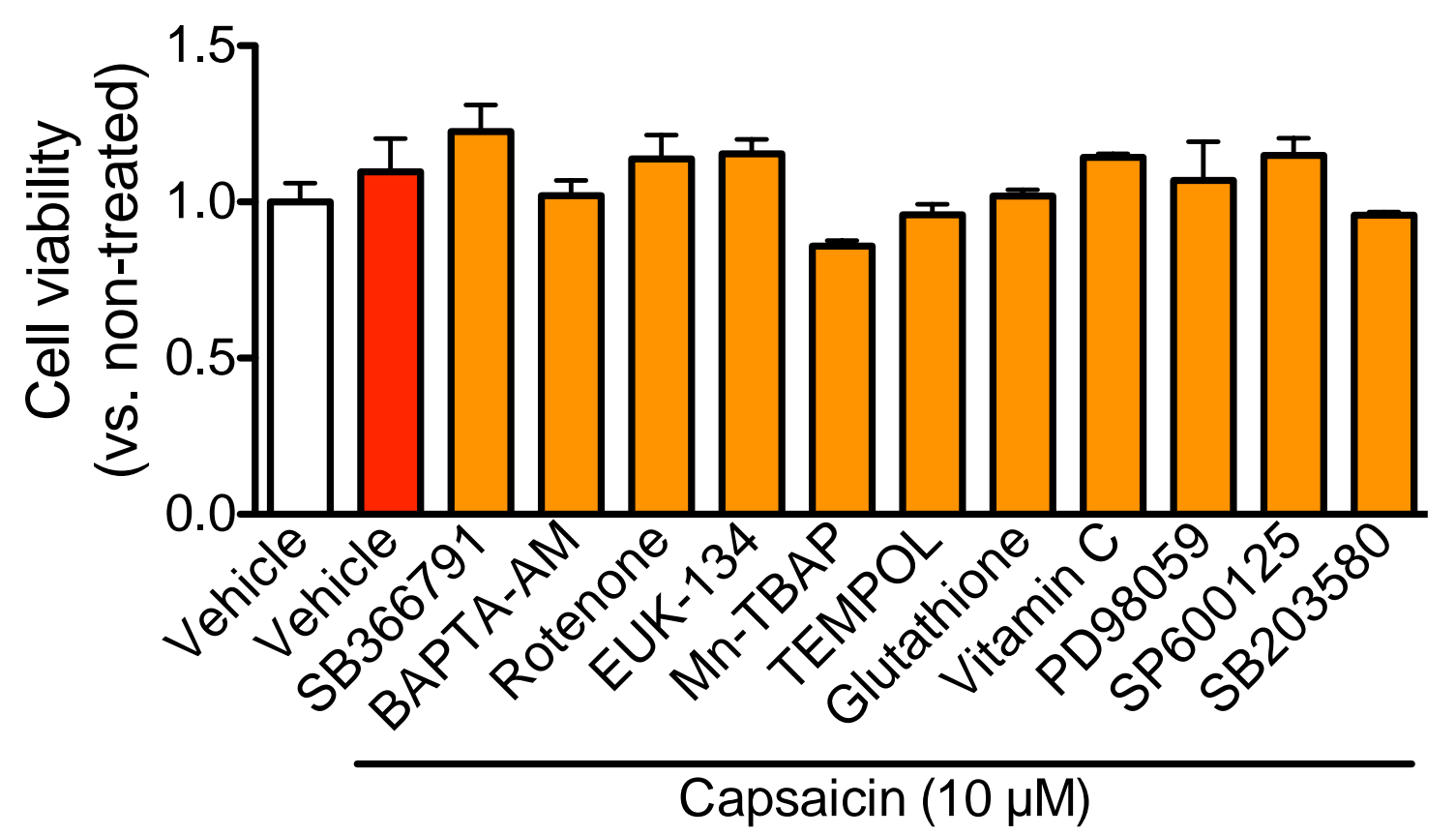

Miyake et al., 2015, Supplemental information Fig. S2

Wild-type microglia were treated with vehicle (white), capsaicin $(10 \mu \mathrm{M})$ alone (red) or an inhibitor (SB366791 $(3 \mu \mathrm{M})$, BAPTA-AM $(10 \mu \mathrm{M})$, rotenone (3 $\mu \mathrm{M})$, EUK-134 $(3 \mu \mathrm{M})$, Mn-TBAP $(30 \mu \mathrm{M})$, TEMPOL (1 mM), glutathione $(1 \mathrm{mM})$, vitamin $\mathrm{C}(100 \mu \mathrm{M})$, PD98059 $(10 \mu \mathrm{M})$, SP600125 $(30 \mu \mathrm{M})$ or SB203580 $(30 \mu \mathrm{M})$ ) in addition to capsaicin (orange). After $24 \mathrm{~h}$, all the supernatant was replaced to the medium containing 3-(4,5-dimethyl-2-thiazolyl)-2,5-diphenyltetrazolium bromide (MTT, 0.05 $\mathrm{mg} / \mathrm{mL}$ ) and further incubated for $2 \mathrm{~h}$, followed by solubilization with dimethyl sulfoxide, and then the absorbance at $570 \mathrm{~nm}$ was measured. Cell viability was calculated as a ratio of the non-treated group (white). $n=3$. Data are presented as means with SEM. 


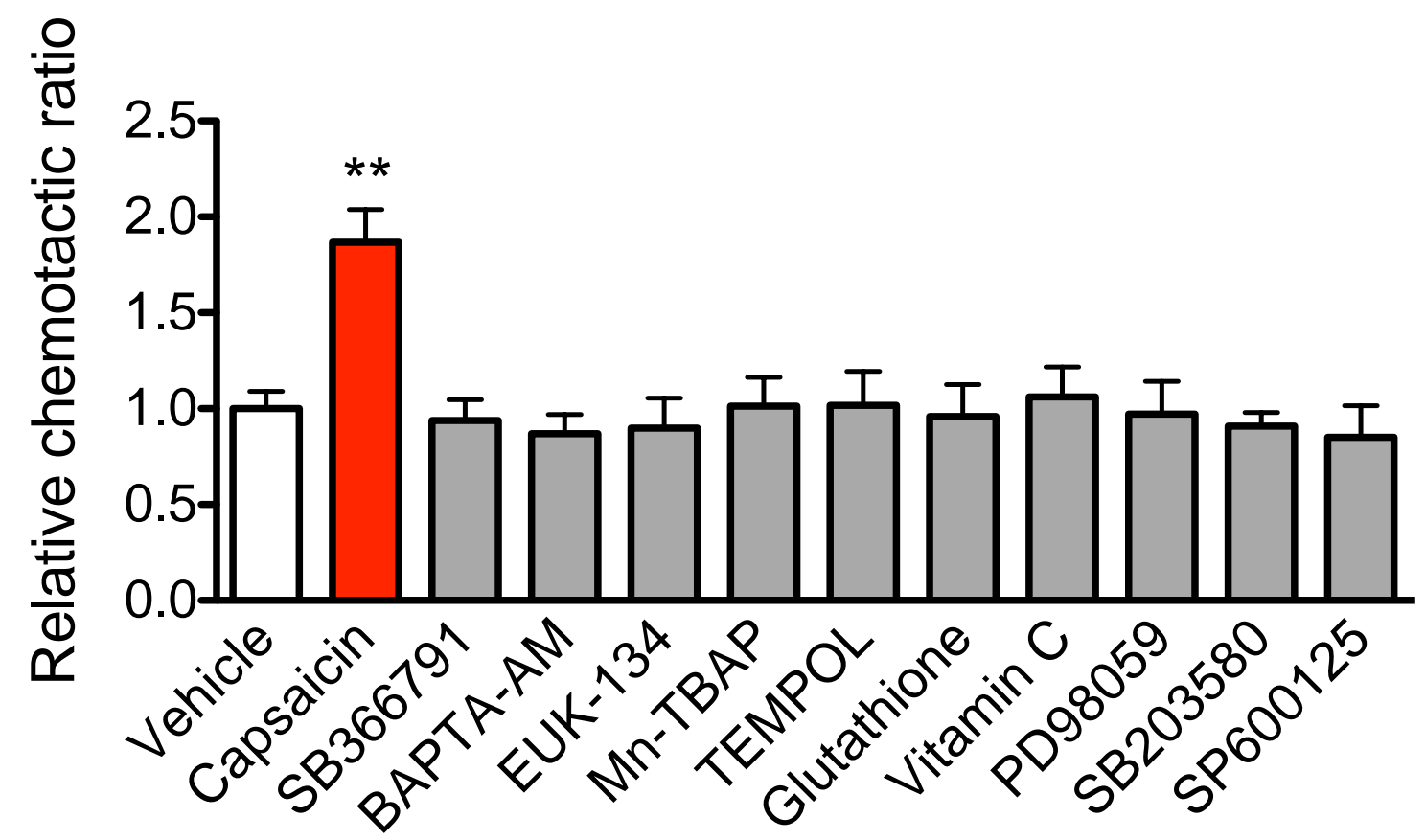

Miyake et al., 2015, Supplemental information Fig. S3

Chemotactic activity of wild-type microglia induced by vehicle (white), capsaicin $(10 \mu \mathrm{M}$, red) or an inhibitor alone (SB366791 $(3 \mu \mathrm{M})$, BAPTA-AM $(10 \mu \mathrm{M})$, EUK-134 $(3 \mu \mathrm{M})$, Mn-TBAP (30 $\mu \mathrm{M})$, TEMPOL (1 mM), glutathione $(1 \mathrm{mM})$, vitamin $\mathrm{C}(100 \mu \mathrm{M})$, PD98059 $(10 \mu \mathrm{M})$, SP600125 $(30 \mu \mathrm{M})$ or SB203580 $(30 \mu \mathrm{M})$, gray) was quantitated with the chemotactic assay. ${ }^{* *} p<$ 0.01 vs vehicle; $n=4$. Data are presented as means with SEM. 


\section{$\square$ Vehicle \\ $\square$ Capsaicin $(10 \mu \mathrm{M})$}

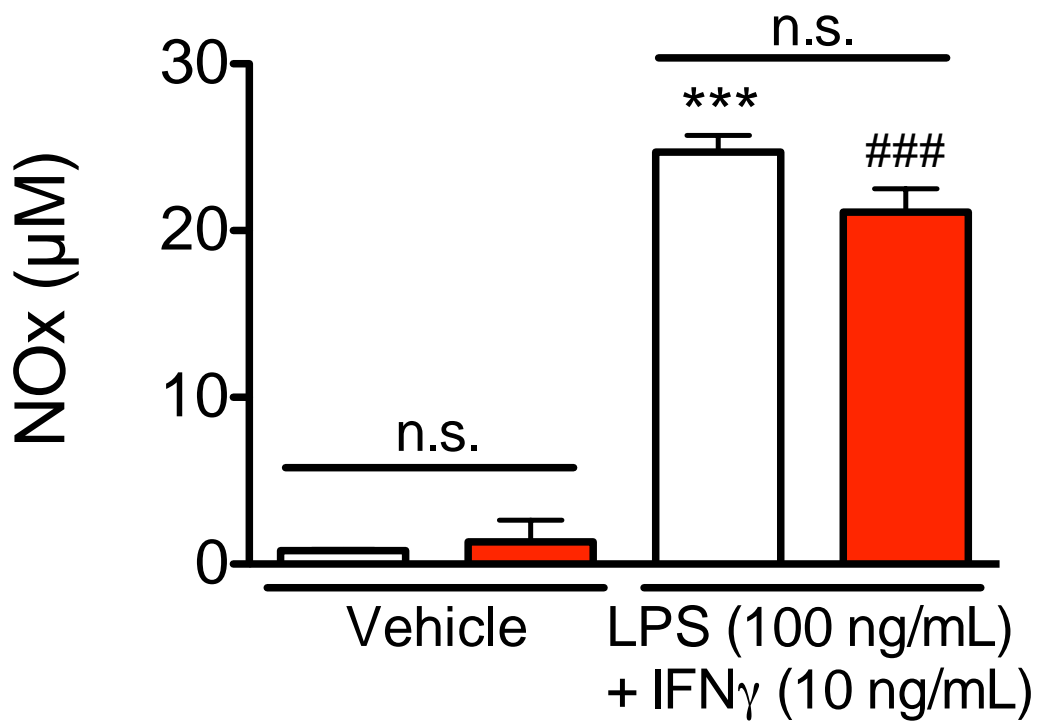

Miyake et al., 2015, Supplemental information Fig. S4

Wild-type microglia was treated with capsaicin $(10 \mu \mathrm{M})$ and/or LPS (100 $\mathrm{ng} / \mathrm{mL})+\operatorname{IFN} \gamma(10 \mathrm{ng} / \mathrm{mL})$ for $48 \mathrm{~h}$ and the concentration of NO in the media was determined using the Griess reaction. ${ }^{* * *} p<0.001$ vs. vehicle/vehicle treated group, \#\#p $<0.001$ vs capsaicin/vehicle treated group, n.s.: not significant; $n=3$. Data are presented as means with SEM. 